\title{
The socioecohydrology of rainwater harvesting in India: understanding water storage and release dynamics across spatial scales
}

\author{
Kimberly J. Van Meter ${ }^{1}$, Michael Steiff ${ }^{2}$, Daniel L. McLaughlin ${ }^{3}$, and Nandita B. Basu ${ }^{1,2}$ \\ ${ }^{1}$ Department of Earth and Environmental Sciences, University of Waterloo, Waterloo, Ontario N2L 3G1, Canada \\ ${ }^{2}$ Department of Civil and Environmental Engineering, University of Waterloo, Waterloo, Ontario N2L 3G1, Canada \\ ${ }^{3}$ Department of Forest Resources and Environmental Conservation, Virginia Tech, Blacksburg, Virginia 24061, USA
}

Correspondence to: Nandita B. Basu (nandita.basu@uwaterloo.ca)

Received: 21 October 2015 - Published in Hydrol. Earth Syst. Sci. Discuss.: 20 November 2015

Revised: 29 March 2016 - Accepted: 18 April 2016 - Published: 7 July 2016

\begin{abstract}
Rainwater harvesting (RWH), the small-scale collection and storage of runoff for irrigated agriculture, is recognized as a sustainable strategy for ensuring food security, especially in monsoonal landscapes in the developing world. In south India, these strategies have been used for millennia to mitigate problems of water scarcity. However, in the past 100 years many traditional RWH systems have fallen into disrepair due to increasing dependence on groundwater. This dependence has contributed to accelerated decline in groundwater resources, which has in turn led to increased efforts at the state and national levels to revive older RWH systems. Critical to the success of such efforts is an improved understanding of how these ancient systems function in contemporary landscapes with extensive groundwater pumping and shifted climatic regimes. Knowledge is especially lacking regarding the water-exchange dynamics of these RWH tanks at tank and catchment scales, and how these exchanges regulate tank performance and catchment water balances. Here, we use fine-scale, water-level variation to quantify daily fluxes of groundwater, evapotranspiration (ET), and sluice outflows in four tanks over the 2013 northeast monsoon season in a tank cascade that covers a catchment area of $28 \mathrm{~km}^{2}$. At the tank scale, our results indicate that groundwater recharge and irrigation outflows comprise the largest fractions of the tank water budget, with ET accounting for only $13-22 \%$ of the outflows. At the scale of the cascade, we observe a distinct spatial pattern in groundwater-exchange dynamics, with the frequency and magnitude of groundwater inflows increasing down the cascade of tanks. The significant magnitude of re-
\end{abstract}

turn flows along the tank cascade leads to the most downgradient tank in the cascade having an outflow-to-capacity ratio greater than 2. At the catchment scale, the presence of tanks in the landscape dramatically alters the catchment water balance, with runoff decreasing by nearly $75 \%$, and recharge increasing by more than $40 \%$. Finally, while water from the tanks directly satisfies $\sim 40 \%$ of the crop water requirement across the northeast monsoon season via surface water irrigation, a large fraction of the tank water is "wasted", and more efficient management of sluice outflows could lead to tanks meeting a higher fraction of crop water requirements.

\section{Introduction}

Issues of water stress are now estimated to impact more than one-third of the global population, and it is predicted that this fraction will nearly double as the world reaches peak population (Wada et al., 2014). Such increases in water stress are driven not only by a growing population, changing patterns of food consumption and climate-driven changes in water availability (Wiltshire et al., 2013) but also by spatial and temporal mismatches between water availability and water demand (Oki, 2006). From a spatial perspective, regional per capita water availability can vary drastically from more than $50000 \mathrm{~m}^{3} \mathrm{yr}^{-1}$ to less than $500 \mathrm{~m}^{3} \mathrm{yr}^{-1}$ (Parish et al., 2012; Wada et al., 2014), with levels of water stress in one basin having little impact on that in another. Similarly, temporal mismatches, particularly in areas with high seasonal rainfall 
variability, can create high rates of runoff leading to flood events and high short-term availability during wet seasons, followed by severe water stress during dry periods (Haile, 2005). Such temporal mismatches, paired with a shortage of surface water storage, have been linked to both reduced incomes and a lack of food security (Gohar et al., 2013; Grey and Sadoff, 2007).

Both spatial and temporal mismatches in water stress and availability characterize the climatic regime of India. The monsoon-driven climate common to semi-arid areas of India results in remarkable temporal variation where it is common for half of the year's total rainfall to fall over a period of only $20 \mathrm{~h}$ (Keller et al., 2000). With such limited annual water availability and the extreme intra-annual rainfall variability, there have been ongoing efforts in India to increase storage capacity and additional water supplies for agricultural production and economic development (Grey and Sadoff, 2007). Over the last century, such efforts have focused primarily on large-scale projects designed to ensure higher levels of water storage and availability, such as the building of large dams and canal systems (Cullet and Gupta, 2009; Mehta, 2001). For millennia, however, India has met the demand for seasonal water storage and increased water availability at the local level via the building of village-scale rainwater harvesting (RWH) structures, often referred to as tanks (Van Meter et al., 2014).

It is estimated that more than 39000 of these RWH tanks are present in the southern Indian state of Tamil Nadu, which is the focus of the present study (Van Meter et al., 2014). These RWH tanks, which commonly take the form of earthen impoundments, 20-40 ha in size (Gunnell and Krishnamurthy, 2003), are built up from natural depressions in the landscape and have historically been designed to meet the water needs of subsistence-level farmers for rice production via managed sluice channels for irrigation (Farmer, 1977). Tanks are often linked in a cascade with overflow from the upstream tanks spilling into surplus channels that lead to downstream tanks. The tank systems have fallen into decline in recent decades, primarily as a result of increasing reliance on groundwater pumping, and cheap access to electricity. This has led to declining groundwater levels, which, coupled with a growing demand for increased agricultural production, have led to renewed interest in these traditional systems (Kumar et al., 2008; Shah, 2004). Although the majority of existing RWH tanks still remain in a state of disrepair (Anbumozhi et al., 2001), it is estimated that reviving RWH systems at an all-India scale could potentially add as much as $125 \mathrm{~km}^{3} \mathrm{yr}^{-1}$ to the country's current water supply, making them critical in meeting the projected water shortfall of $300 \mathrm{~km}^{3} \mathrm{yr}^{-1}$ by 2050 (Gupta and Deshpande, 2004). Consequently, in India's Groundwater Recharge Master Plan (2005), the need for renovation or new construction of RWH structures was highlighted at a cost of approximately USD 6 billion, leading to high rates of revival of RWH structures across India (Agarwal and Narain, 1997; Shah et al., 2009)

With the renewed and large-scale interest in the use of RWH structures (Garg et al., 2013; Rockstrom et al., 2002; van der Zaag and Gupta, 2008), it is critically important to ask whether these ancient structures perform their intended purpose of significantly improving water availability in a basin (Batchelor et al., 2003; Bouma et al., 2011; Calder et al., 2008a, b; Garg et al., 2013). To do so requires quantifying the dominant tank inflows and outflows, specifically evapotranspiration (ET), groundwater recharge, and sluice outflows to irrigated fields. These water fluxes determine relative water allocation to aquifer supplies, irrigation needs, and atmospheric losses, and are influenced by a wide range of both natural and management controls, from climate and geology to the more direct anthropogenic controls (e.g., sluice outflow regulation). As such, a better understanding of tank fluxes and drivers of these fluxes is necessary when managing individual and cascades of tanks to meet both societal (irrigation demand) and environmental (increasing rates of groundwater recharge) needs (Glendenning et al., 2012; Neumann et al., 2004; Ngigi, 2003).

Unfortunately, there is a lack of empirical studies that quantify tank hydrologic fluxes, especially at the scale of watersheds comprising of multiple tanks (Glendenning et al., 2012; Mialhe et al., 2008; Pandey et al., 2011, 2013). One reason for the lack of information is that both groundwater recharge and ET are highly spatially variable, and thus difficult to accurately measure at the field scale (Glendenning et al., 2012). Most previous studies of RWH tanks estimate recharge as a residual term in the water-balance method (Glendenning et al., 2012); in arid environments, however, recharge magnitude is small compared to other fluxes (Bond, 1998), making estimates from water balance residuals vulnerable to errors in other measured components. Furthermore, water-balance methods used in RWH tanks estimate recharge using modeled values of tank evapotranspiration, another rarely measured but critically important water flux in these arid environments (Sharda et al., 2006). While there is consensus regarding the value of direct measurements of temporal variations in recharge and evapotranspiration fluxes from RWH structures, such data are difficult to obtain due to the inherent complexities in making these measurements, especially under resource constraints (Glendenning et al., 2012).

Here, we propose an innovative use of the White (1932) method as a cost-effective means of obtaining spatially integrated, direct measurements of both ET and groundwater exchange in flooded RWH tanks. The White method, which was originally developed to estimate the magnitude of groundwater consumption by phreatophytes (Loheide, 2008; Loheide et al., 2005), has since been used to estimate ET and groundwater exchange in small, surface water systems (Carlson Mazur et al., 2014; Hill and Durchholz, 2015; McLaughlin and Cohen, 2013). In these systems, diurnal variations 
Table 1. Population and land-use data for the study cascade.

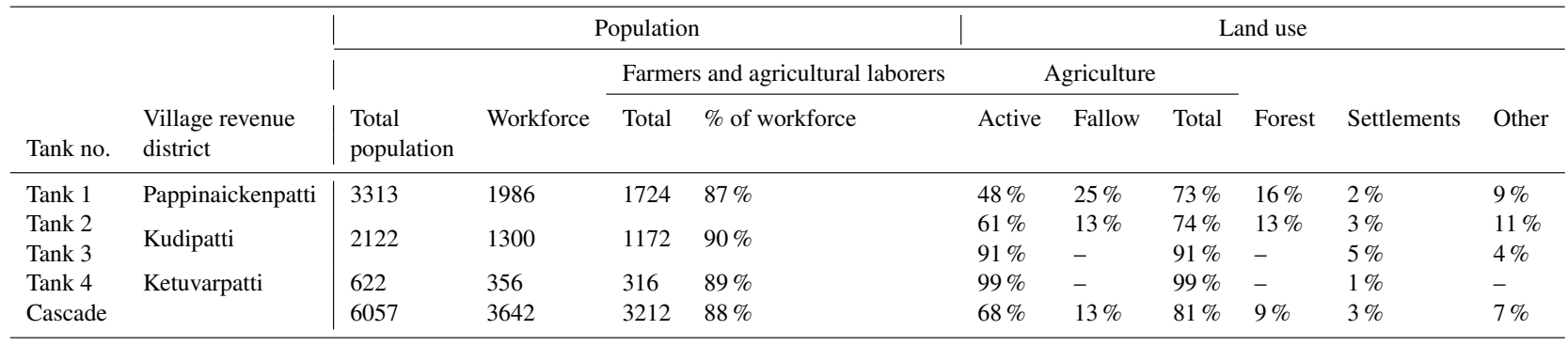

(a)

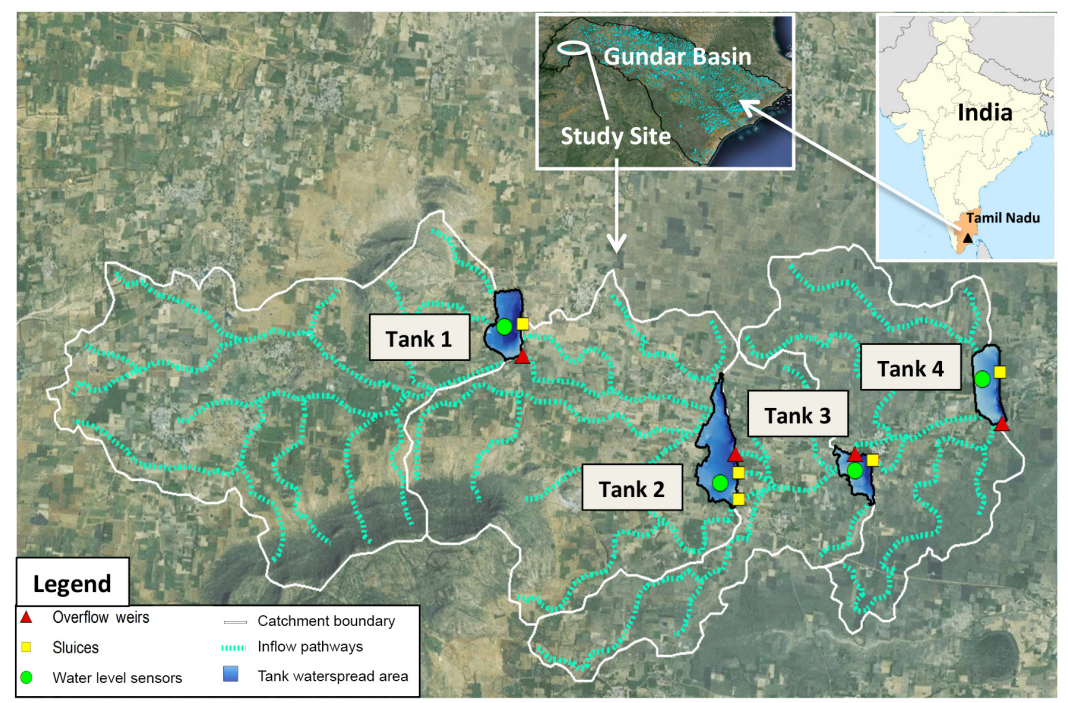

(b)

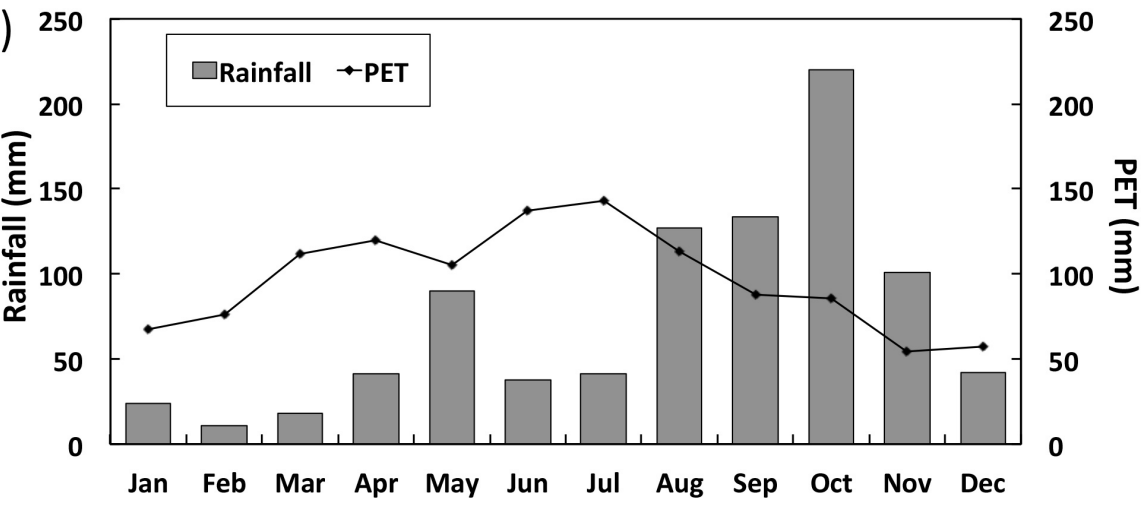

Figure 1. (a) Location of the Thirumal Samudram cascade within Tamil Nadu. The dotted lines indicate flowpaths calculated based on a digital elevation map (DEM) for the area; (b) average rainfall and potential evapotranspiration (PET) (1900-1970) measured at Peraiyur weather station, $10 \mathrm{~km}$ from the study cascade.

in high-resolution surface water level data are used to decouple ET dynamics from groundwater exchange. In this paper, we demonstrate an application of this method to RWH structures, which are more complex than the systems studied thus far in that they have additional outflows (overflow and sluice outflow), and are much larger in spatial extent ( $\sim 1$ ha vs. $20-60$ ha). Furthermore, while most studies of
RWH systems have focused on individual tanks, we explore how groundwater-exchange dynamics change along a tank cascade made up of four tanks, and scale up measured fluxes to estimate cumulative effects of tanks on catchment water balances. Our study has two linked objectives: (1) to quantify temporal patterns in groundwater exchange, ET, and sluice outflows over the northeast monsoon season; and (2) to de- 
scribe spatial patterns of measured fluxes from upstream to downstream tanks in a cascade. Using these estimates, we attempt to answer the following questions:

- At the local scale, how do tanks partition water, and what is the spatial variability in this partitioning behavior along a tank cascade?

- At the catchment scale, how do tanks alter the water balance in a basin?

- What percentage of the irrigation requirements do tanks meet, and can they be managed more efficiently to increase this fraction?

\section{Study area}

\subsection{Site description}

The study site is located in the south Indian state of Tamil Nadu, in the foothills of the Western Ghats mountain range (Fig. 1a). The region surrounding the tank cascade is semiarid, receiving a mean annual rainfall of $850 \mathrm{~mm}$, with $50 \%$ of that falling during the northeast monsoon season (October-December) (Government of Tamil Nadu, 2011; Vose et al., 1992). ET is greater than rainfall from January through July, while it is less than rainfall during the monsoon months (Fig. 1b). For the year in which the field study was done (2013), rainfall over the northeast monsoon season (October-December) was $355 \mathrm{~mm}$, which is close to the 70 -year average of $363 \mathrm{~mm}$.

The focus of the study is the Thirumal Samudram (TS) tank cascade, a hydrologically connected group of four rainwater harvesting tanks that encompass an overall catchment area of $28 \mathrm{~km}^{2}$, in the Madurai district of Tamil Nadu near the headwaters of the Gundar river basin (Fig. 1a). All four tanks in the cascade have undergone renovation through a joint effort of local stakeholders and the Development of Humane Action (DHAN) Foundation, an NGO group leading tank rehabilitation efforts across south India (DHAN, 2010), including regular desiltation, strengthening of tank bunds, and repair of surplus and sluice weirs. The four tanks provide irrigation water for three village revenue districts: Pappanaickenpatti (Tank 1), Kudipatti (Tanks 2 and 3), and Ketuvarpatti (Tank 4), from upstream to downstream. The population of the tank cascade area is 6057 (Government of India, 2011), and $88 \%$ of the working population hold jobs either as farmers or agricultural laborers (Table 1).

The landscape surrounding the tank cascade has a gentle slope, ranging $0.5-1.0 \%$, and is characterized by Alfisol and Vertisol soils underlain by fractured rock of granitic origin (CGWB, 2012; ICRISAT, 1987; Palaniappan et al., 2009). Land use for the study area is primarily agricultural. Within the study cascade, $81 \%$ of the land is devoted to agricultural use, with $42 \%$ of this total being irrigated (Table 1) (DHAN, 2010). During the northeast monsoon season
(October-January), paddy (rice) is the primary crop in the region, while during other periods of the year, a variety of other crops are cultivated, including cotton, groundnuts, and pulses (Government of Tamil Nadu, 2011).

\subsection{Rainwater harvesting structures}

Tanks in south India are created through the construction of an earthen dam (bund) across depressional areas in the landscape as a means of storing surface runoff (Van Meter et al., 2014) (Fig. 2). During elevated water levels, flooding extends beyond the main depressional area and into flatter, often farmed areas (i.e., tank water spread area). The bunds are constructed using locally available materials, usually a combination of amassed earth and stones, supported by the roots of trees and bushes growing along the bunds (Weiz, 2005). Sluices (typically sliding gates) are constructed within the tank bund and are used to control the release of water into irrigation channels, which then transport the stored water to agricultural fields in the downstream tank command area (i.e., fields irrigated by tank water. During heavy monsoon rains, water may spill over the tank's overflow weir into surplus channels leading to downstream tanks or to nearby waterways (Van Meter et al., 2014). Tanks are often linked through these surplus channels in chains or cascades that can range in size from several to more than a hundred tanks, forming a dense hydrological network across this intensively managed agricultural landscape.

Tank storage capacities vary across sites and time, with the latter due to siltation and desiltation cycles (Weiz, 2005). Historical data regarding maximum tank area and storage volumes for the four study tanks, obtained by the Public Works Department in India in approximately 1900, are summarized in Table 2 (DHAN, 2010). Information regarding the tank irrigated area, also known as the command area or "ayacut" (Weiz, 2005), is also provided. Although the maximum water depths of the four tanks are similar, ranging from 3$4 \mathrm{~m}$ at maximum fill, the historical data show that the tank areas vary significantly, ranging from 19.3 ha (Tank 3) to 58.7 ha (Tank 2). The ratio of command area to tank area historically ranged between 0.77 and 1.25 (Table 2), which is characteristic of tank systems found in this area (von Oppen and Subba Rao, 1987; Weiz, 2005). Table 2 also includes measurements made in the present study for comparison (discussed later).

\section{Methods}

\subsection{Field methods: sensor installation and bathymetric survey}

Tank water levels were continuously measured during and in the months immediately following the 2013 northeast monsoon season (October 2013-February 2014) using total pressure transducers (Solinst Levelogger Edge, accuracy 


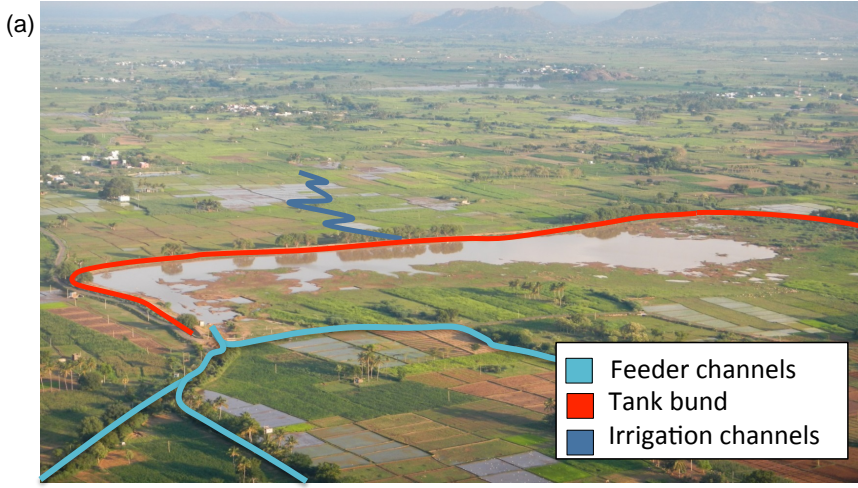

(b)

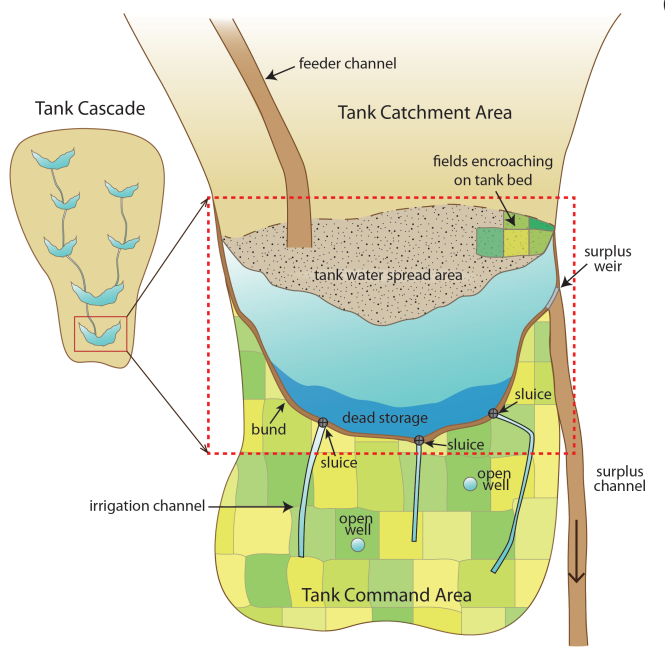

(c)

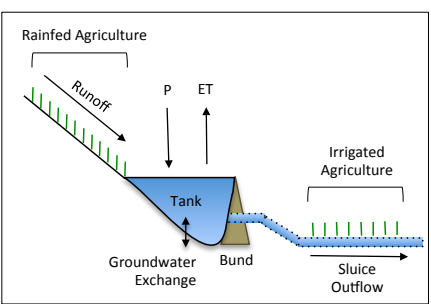

Figure 2. (a) Aerial view of Tank 4 in the Thirumal Samudram cascade; (b) plan view of a typical tank along with catchment and command area (Van Meter et al., 2014); (c) cross section showing tank water budget components.

Table 2. Summary of tank attributes based on historical tank data and the current study. Current tank capacity is based on our measurements, while historical tank capacity is based on Public Works Department data (DHAN, 2010).

\begin{tabular}{|c|c|c|c|c|c|c|c|c|}
\hline \multirow[b]{2}{*}{ Tank no. } & \multirow[b]{2}{*}{ Soil type } & \multirow[b]{2}{*}{$\begin{array}{l}\text { Maximum } \\
\text { depth (m) }\end{array}$} & \multirow[b]{2}{*}{$\begin{array}{l}\text { Maximum tank } \\
\text { surface area (ha) }\end{array}$} & \multirow[b]{2}{*}{$\begin{array}{l}\text { Tank command } \\
\text { area (ha) }\end{array}$} & \multicolumn{4}{|c|}{ Tank capacity $\left(\mathrm{m}^{3}\right)$} \\
\hline & & & & & $\begin{array}{l}\text { Command area/ } \\
\text { surface area ratio }\end{array}$ & Historical & Current & $\begin{array}{l}\text { Current capacity/ } \\
\text { historical capacity }\end{array}$ \\
\hline Tank 1 & Alfisol & 3.2 & 15 & 27 & 0.96 & 357700 & 276405 & 0.77 \\
\hline Tank 2 & Vertisol & 3.4 & 51 & 45 & 0.77 & 656500 & 407513 & 0.62 \\
\hline Tank 3 & Vertisol & 4.0 & 14 & 19 & 0.93 & 237000 & 217633 & 0.92 \\
\hline Tank 4 & Vertisol & 3.3 & 21 & 24 & 1.25 & 168000 & 139270 & 0.83 \\
\hline
\end{tabular}

of $\pm 0.3 \mathrm{~cm}$, resolution of $0.01 \mathrm{~cm}$; Solinst Canada, Georgetown, Ontario, Canada) installed in wells at the deepest point of each tank. Wells constructed of 10-gage PVC, were installed to a belowground depth of $70 \mathrm{~cm}$ and were screened above and below the ground surface. The pressure transducers measured total pressure $\left(\mathrm{m} \mathrm{H}_{2} \mathrm{O}\right)$ at 5 min intervals, and these measurements were corrected for variations in barometric pressure based on measurements collected at the same intervals with barometric pressure transducers (Solinst Barologger, accuracy of $\pm 0.5 \mathrm{~cm}( \pm 0.05 \mathrm{kPa})$, resolution of $0.001 \mathrm{~cm}(0.0001 \mathrm{kPa}))$. Slug tests were used to measure soil hydraulic conductivity $\left(K_{\text {sat }}\right)$ in the installed wells using the Hvorslev (1951) method. Barometric pressure transducers were installed in dry wells open to atmospheric pressure but below ground to avoid changes in temperature and known temperature sensitivities (McLaughlin and Cohen, 2014). Corrected tank stage data were verified based on direct stage measurements at the study site. Pressure transducers were installed on 26 September before the start of the rainy season, and retrieved on 20 January for Tanks 1 and 
2, and 7 March for Tanks 3 and 4, generally when wells became dry. Continuous precipitation was measured using Onset RG3-M automatic tipping bucket rain gages (Onset Computer Corporation, Bourne, MA) installed near each of the four tanks.

Bathymetric surveys were conducted using a combination of measured water depths in flooded areas (i.e., ground elevations relative to water surface) and a Trimble ProXRT2 GPS receiver paired with a Juno handheld computer for absolute ground elevations in exposed areas. Since Tank 4 had a large number of acacia trees that interfered with the accuracy of the Trimble, a Sokkia total station was used for ground elevation surveys. A total of 16-24 transects at a grid spacing of $40 \mathrm{~m}$ were taken in each tank, and all surveyed elevations were converted to ground elevations relative to the tank base (lowest point), which was defined as zero. The bathymetric data were used to create stage-volume and area-volume relationships for each tank, and estimate current tank capacities. The capacities estimated by this method led to reasonable values, with current capacities ranging between 62 and $92 \%$ of the historical capacities (Table 2).

\subsection{Sluice and overflow weir outflow estimates}

There are six sluices in the study area, two in Tank 1, two in Tank 2, and one each in Tanks 3 and 4 . Water release from the sluices is controlled by a sluice gate that can be opened to different degrees by a sluice rod. For our study tanks, the degree of sluice openness remained primarily unchanged during the period of study, and thus the major factor that controlled sluice discharge was the tank water level. To understand this relationship, sluice discharge was estimated at different tank water levels. Discharge was estimated by measuring the velocity and cross-sectional area over a chosen section of each outflow channel just downstream from the sluice outlet. This section was selected based on width uniformity and channel straightness. Approximately $20-40$ measurements were made during each discharge measurement to obtain a reliable velocity estimate. Stage-discharge relationships developed for each sluice were used to estimate volumetric daily sluice outflow rates; these rates were then converted to areanormalized rates $\left(S_{0}, \mathrm{~cm} \mathrm{~d}^{-1}\right)$ based on tank stage-area relationships (Sect. 3.1).

As described in Sect. 2.2, in addition to water loss via sluice outflow, water may also flow out of the tank by spillage through the overflow weir into surplus channels during large storm events. Overflow was observed during the study period only in the case of Tank 4 on 20 October, during the first major rains of the monsoon season. For this event, the surplus flow volume was estimated based on the observed drop in water levels between 20 and 21 October.

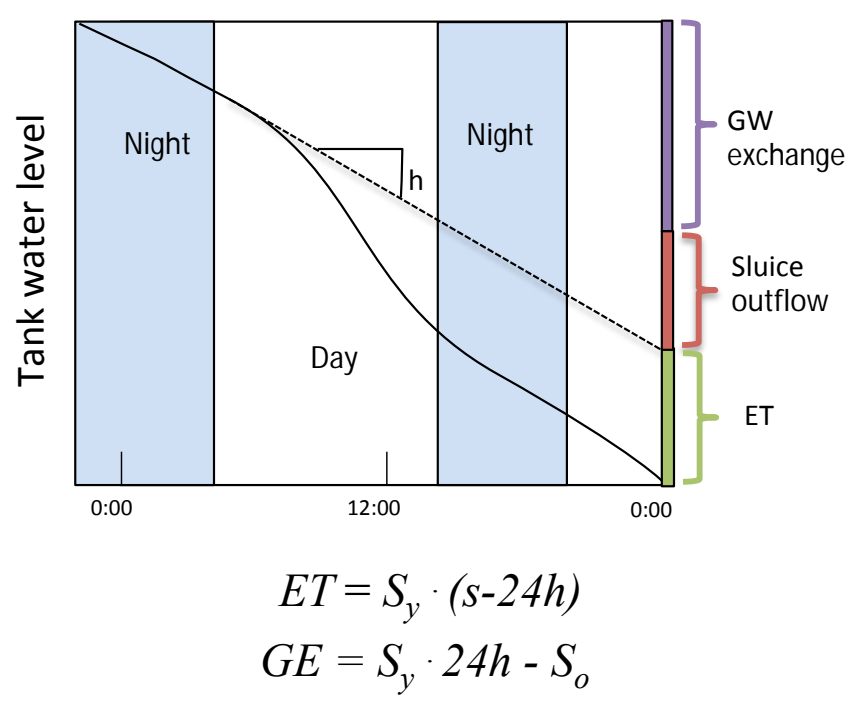

Figure 3. The White method for estimating ET and groundwater exchange using diurnal water level fluctuations. Grey bars denote nighttime.

\subsection{Estimation of groundwater recharge and evapotranspiration}

The White (1932) method was used to calculate daily ET and net groundwater exchange from high-resolution stage data on days with no rainfall (Fig. 3). The White method is based on two central assumptions: (1) ET $\left(\mathrm{cm} \mathrm{d}^{-1}\right)$ fluxes are negligible at night, enabling groundwater flows to be estimated from nighttime stage changes, and (2) there is no diurnal variation in the groundwater exchange $\left(\mathrm{GE} ; \mathrm{cm} \mathrm{d}^{-1}\right)$. Additionally, we have assumed that there is no surface inflow to the RWH tanks on days when it is not raining, which implies that overland flow occurs over very short time intervals. This is a reasonable assumption with the monsoonal rainfall dynamics that are characteristic of this region. Here, the White method was also modified to account for sluice outflow $\left(S_{0} ; \mathrm{cm} \mathrm{d}^{-1}\right)$, which occurred both night and day in our study.

ET and GE $\left(\mathrm{cm} \mathrm{d}^{-1}\right.$; positive values indicate tank outflow or recharge) were estimated using the following equations:

$$
\begin{aligned}
& \mathrm{ET}=S_{\mathrm{y}} \times\left(s-24 h_{\mathrm{n}}\right) \\
& \mathrm{GE}=S_{\mathrm{y}} \times 24 h_{\mathrm{n}}-S_{\mathrm{o}},
\end{aligned}
$$

where $S_{\mathrm{y}}$ is the specific yield (dimensionless), $s(\mathrm{~cm})$ is the $24 \mathrm{~h}$ stage change (positive values indicate net stage decline), and $h_{\mathrm{n}}\left(\mathrm{cm} \mathrm{h}^{-1}\right)$ is the slope of the nighttime decline in water level between 12 p.m. and 5 a.m. Since sluice outflow occurs throughout the day and night, the nighttime slope $\left(h_{\mathrm{n}}\right)$ includes both $S_{0}$ and GE, and thus ET can be estimated as the difference between the $24 \mathrm{~h}$ drop in water level (s) and $h_{\mathrm{n}}$ scaled to the daily rate (Eq. 1). Because only GE and $S_{0}$ occur at night, GE can be estimated by subtracting $S_{0}$ from the nighttime hourly slope $h_{\mathrm{n}}$ scaled to a daily rate, and after accounting for the specific yield. Specific yield $\left(S_{\mathrm{y}}\right)$ is defined 
as the volume of water released from or added to storage in porous media divided by the total volume of the system (Healy and Cook, 2002). On a per-unit-area basis, $S_{\mathrm{y}}$ represents the input (rain) or output (ET) depth divided by the observed change in the water level.

In our study, $S_{\mathrm{y}}$ was set to 1.0 , following the common assumption for flooded areas (Mitsch and Gosselink, 2007). It should be noted, however, that $S_{\mathrm{y}}$ values in soils can range from 0.1 to 0.35 (Loheide et al., 2005), meaning that belowground water levels experience a greater decline than flooded areas for an equal ET flux. At the edge of a surface water body, this difference in water levels can lead to the formation of a hydraulic gradient, and thus to water subsidy from the flooded area to adjacent exposed areas. In soils allowing rapid equilibration of water levels, daytime declines from the flooded area would thus lead to subsidy to adjacent exposed areas (McLaughlin and Cohen, 2014). Under these circumstances, ET estimated via the White method using $S_{\mathrm{y}}=1.0$ would include both ET from standing water and any daytime flux to adjacent exposed areas to equilibrate greater ETinduced declines in belowground water levels. Such rapid equilibration between flooded areas and adjacent exposed areas was observed by McLaughlin and Cohen (2014) when applying the White method to estimate wetland ET in the sandy soils of Florida (hydraulic conductivity $K_{\text {sat }}=1.13-$ $6.42 \mathrm{~m} \mathrm{~d}^{-1}$ ). In our study area, however, soils are more clay dominated, and $K_{\text {sat }}$ values for the tanks were measured to be $0.024-0.17 \mathrm{~m} \mathrm{~d}^{-1}, 1-2$ orders of magnitude lower than those for the Florida sites. These very low $K_{\text {sat }}$ values suggest that any rapid equilibration (if any) would likely be limited to small edges, and thus a $S_{\mathrm{y}}$ value of 1.0 is a reasonable assumption. Moreover, measured losses in surface water are still valid and accurate components of the tank surface water budget regardless of the degree to which equilibration occurs. That is, if exposed areas are equilibrating with flooded areas, then the measured surface water decline will include both the direct flux (ET or GE) in the flooded area $\left(S_{\mathrm{y}}=1\right)$ and the subsidy (indirect flux) to equilibrate those exposed areas where $S_{\mathrm{y}}<1$. In this case, the loss in surface water depth is still loss due to a particular flux (ET or GE), just over a greater footprint (i.e., direct fluxes in flooded areas + indirect losses to equilibrate flux-driven declines in adjacent areas). Therefore, when we convert ET and GE depth losses to surface water volume losses using stage-to-volume relationships, the estimates are accurate, and useful for discussing the proportions of stored surface water lost due to various water budget components.

\subsection{Tank and catchment water balances}

Volumetric water balance calculations were carried out at both the individual tank and the tank catchment scales across the northeast monsoon season to answer questions regarding the partitioning of rainfall into the various outflow components (e.g., $S_{\mathrm{o}}$, ET, GE). For individual tank water bal- ances, we utilized daily data for water levels, rainfall, $S_{0}$, ET, and GE. For nonrainfall days, ET and GE values were calculated using the White method. For rainfall days, ET and GE could not be calculated directly via the White method, as the method necessarily assumes a constant groundwater flow and therefore cannot account for rainfall-related inputs. This disruption in the continuity of the data set, without correction, would lead to gaps in the daily water balance and an underestimation of both ET and groundwater exchange across the monsoon season. To eliminate these gaps, we estimated ET values on rainfall days via interpolation between White method-estimated ET rates on days without rain. GE on rainfall days was estimated based on the residuals of the daily water balance, using the measured $24 \mathrm{~h}$ change in tank water levels, estimated ET rates, measured precipitation, and estimated runoff into the tank (McLaughlin and Cohen, 2013). Runoff was estimated using the Strange method (Shanmugham and Kanagavalli, 2013), an empirical method that was developed to predict runoff from catchments with irrigation tanks and small reservoirs and that is widely used throughout India by government departments dealing with irrigation (Latha et al., 2012). In this method, daily runoff is calculated as a percentage of daily rainfall, based on tabulated values in which runoff is expressed as a function of (a) rainfall on that day, (b) antecedent rainfall conditions, and (c) catchment characteristics (Shanmugham and Kanagavalli, 2005). The Strange method has been shown to provide results comparable to those obtained with the more commonly used SCS curve number method (Latha et al., 2012), but is more representative of the south Indian conditions that are the focus of our study. Stage-to-area relationships (Sect. 3.1) were used to convert daily stage change and estimated fluxes (ET, GE, and $S_{\mathrm{o}}$ ) into volumes, which were calculated for each tank. Note that the water balances for all tanks are calculated for the period of 17 October 201313 January 2014, a period that spans the entire monsoon season and for which water-level data were available for all four tanks.

Water balances were also calculated at the catchment scale using a nested catchment design for four catchments (Fig. 4): (1) Catchment 1 (C1): Tank 1 (T1) and its contributing catchment; (2) Catchment 2 (C2): Tank 2 (T2) and its contributing catchment, which includes Tank 1 and its catchment area and command area; (3) Catchment 3 (C3): Tank 3 (T3) and its contributing catchment, which includes Tanks 1 and 2, and their catchment and command areas; and (4) Catchment 4 (C4): Tank 4 (T4) and its contributing catchment, which includes Tanks 1, 2, and 3 and their catchment and command areas. This nested catchment design enabled us to explore the effect of varying catchment sizes and tank-to-catchment ratios on the water partitioning.

Further, in order to understand the impact of the tanks at the catchment scale, we explored two scenarios for each of the four catchments scales (i.e., C1-C4): (1) a with-tank (WT) scenario to represent current conditions within the 
catchment (i.e., four existing tanks); and (2) a no-tank (NT) scenario, with all other conditions (e.g., rainfall, ET on the catchment area) being the same. For the NT case, catchmentscale runoff was calculated using the Strange method (Shanmugham and Kanagavalli, 2013) and daily rainfall over the monsoon season. Remaining rainfall was assumed to exit the system through ET and groundwater recharge. For the WT case, we assumed the sluice outflow from the most downstream tank in the catchment ( $\mathrm{T} 1$ for $\mathrm{C} 1, \mathrm{~T} 2$ for $\mathrm{C} 2, \mathrm{~T} 3$ for C3, and T4 for C4) to represent the $Q$ value for each catchment. For T4, a surplus overflow event occurred at the start of the season, the volume of which was estimated based on stage-volume relationships; this volume was added to the sluice outflow to estimate the $Q$ for $\mathrm{C} 4$. The $Q$ values for the NT and WT scenarios were compared for all four catchments to understand the effect of tanks on the catchment runoff.

To understand the effect of tanks on catchment-scale groundwater recharge, we assumed the mean recharge to be $17 \%$ of the mean annual rainfall for the NT case following Anurag et al. (2006). For the WT case, the landscape was assumed to include three different domains, with separate recharge fractions being assumed for each domain: (1) tank bed area: GE (Sect. 3.2) was used; (2) tank command area: $50 \%$ of the sum of rainfall and sluice outflow (based on typical values for paddy fields (Hundertmark and Facon, 2003); and (3) the rest of the watershed: $17 \%$ of rainfall (Anurag et al., 2006). The command area and the tank bed area estimates for the four tanks are provided in Table 2.

\section{Results and discussion}

The current section is divided into two broad subsections. In the first, we report measurements of tank water levels and fluxes (ET and GE), and use these data as a basis for discussing tank water level dynamics across the monsoon season. In the second, we provide analysis of these and complementary data to answer questions regarding controls on the tank and catchment water balances and the ability of tank rainwater harvesting systems to meet irrigation water demand.

\subsection{Tank water-exchange dynamics}

\subsubsection{Tank water levels over the northeast monsoon season}

Water levels in the tanks rose sharply in mid-October following the monsoon rains, and then dropped over the next 3 months as water left the tanks through ET, sluice outflow, and groundwater recharge (Fig. 5). Note that although the northeast monsoon rains began in early September, the tanks started filling only in mid-October. This time lag is likely due to a threshold effect, where runoff to the tanks occurs after cumulative rain volumes begin to exceed catchment infiltration capacity. Two distinct fill events can be observed, one

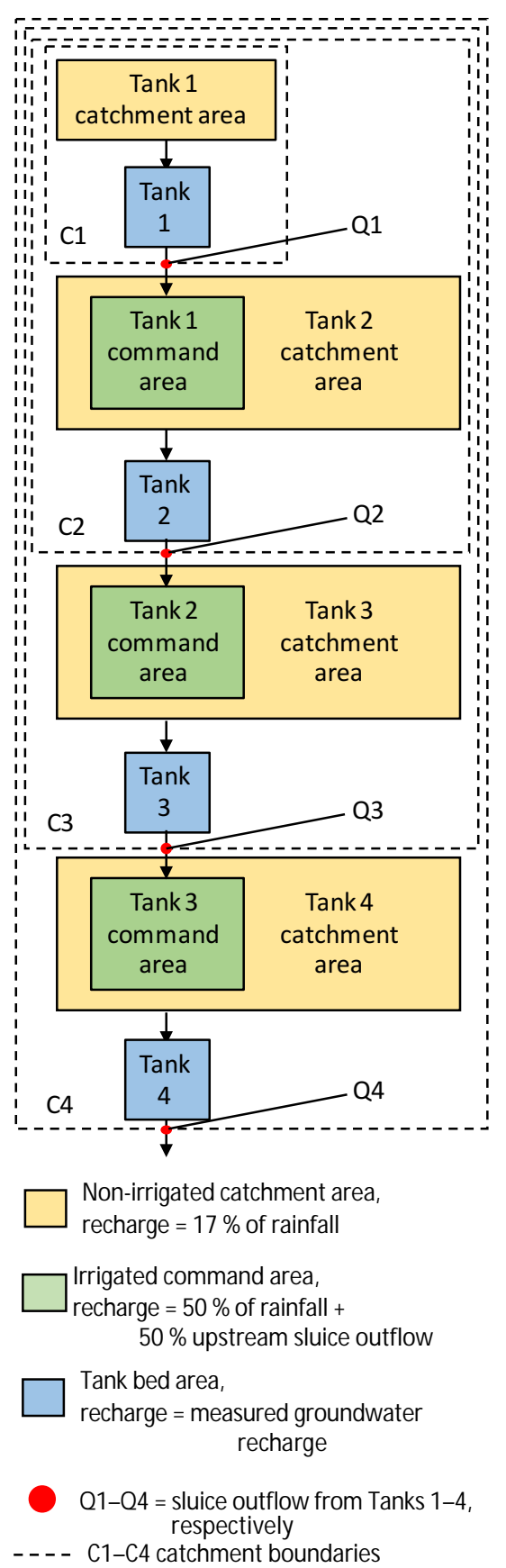

Figure 4. Schematic for the catchment-scale water balance calculations. The dotted lines represent the boundaries, and points Q1-Q4 represent the outlet points for the four nested catchments $\mathrm{C} 1-\mathrm{C} 4$.

on 16 October and the second on 17 November for all tanks except Tank 1, for which the second fill event is not as apparent. Between 16 October and 17 November, the trajectories of Tanks 1 and 3 parallel each other, while those of Tanks 2 and 4 are similar to each other. Towards the latter part of the season, the water-level trajectories of the four tanks approximately parallel each other. Tank 1 loses its water the earliest 


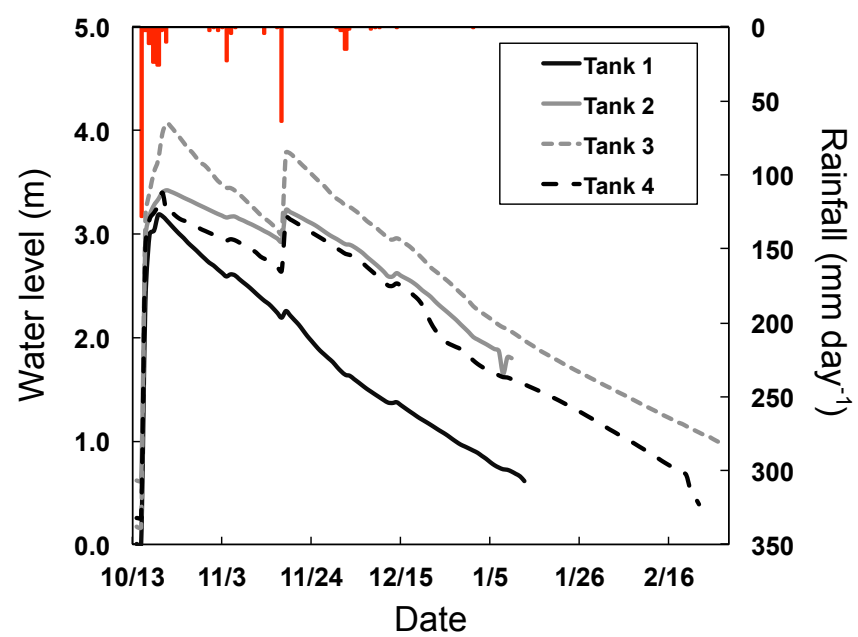

Figure 5. Tank water level and daily rainfall for the four tanks over the northeast monsoon season. Initial water levels are zero, reflecting dry tanks at the start of the monsoon season. Tank water level is measured from the deepest point of the tank. In Tanks 3 and 4, sensors were placed at the deepest points, while in Tanks 1 and 2, sensor wells were offset somewhat from the deepest points due to vegetation in the tank beds. As a result, the time series for Tanks 1 and 2 end earlier than those for the other two tanks.

and is mostly dry by January, while the other three tanks retain some water till February. This difference possibly occurs because Tank 1 overlies Alfisol soils (Table 2), which have higher $K_{\text {sat }}$ values than the clayey Vertisol soils that make up the tank beds of the other three tanks (Pathak et al., 2013). In the following sections, we explore how the outflow fluxes in the four tanks vary over the course of the monsoon season.

\subsubsection{Estimation of evapotranspiration}

ET fluxes estimated with Eq. (1) for the four tanks are shown in Fig. 6. ET rates derived with the White method are reasonable for the region and season potential ET (PET) ca. 3$12 \mathrm{~mm} \mathrm{~d}^{-1}$ for Madurai (Rao et al., 2012), ranging from $5.5 \pm 1.0$ for Tank 1 to $10.1 \pm 0.8 \mathrm{~mm} \mathrm{~d}^{-1}$ for Tank 3 during periods when the tank inundated area is greater than $25 \%$ of maximum area. Below this $25 \%$ threshold (shown in Fig. 6 with dashed line), ET estimates for the tanks exceed PET rates by factors of 2-3. These very high late-season ET values are likely the result of the tanks, at this stage, existing as small areas of flooding surrounded by comparatively extensive areas of exposed soil. Such conditions, particularly in arid regions, can create an oasis effect (Drexler et al., 2004; Paraskevas et al., 2013), in which advection of dry air from exposed areas can increase ET rates in flooded areas beyond typical values (and PET). The magnitude of the oasis effect is known to become greater when the soil is dry and surrounding vegetation is at higher moisture stress (Holmes and Robertson, 1958), thus explaining the significant increase in measured ET values as the landscape dries out late in the monsoon season.

It may also be that an overestimation of the $S_{\mathrm{y}}$ term in Eqs. (1) and (2) could be a contributor to the high measured ET values during late season and low water level conditions. White method calculations by McLaughlin and Cohen (2014) showed ET rates exceeding PET by a factor of 5 or more when flooded areas were small, compared to $\mathrm{ET} / \mathrm{PET} \approx 1.0$ at moderate to maximum flooded areas. As discussed in Sect. 3.3, however, the very low $K_{\text {sat }}$ values in our study area, compared to the much higher values in the McLaughlin and Cohen (2014) study, suggest that any equilibration occurring at the tank edges would be very small in magnitude. Accordingly, the oasis effect, described above, appears to be the most likely explanation of our high ET values.

\subsubsection{Estimation of groundwater exchange}

The temporal pattern of net GE, estimated using Eq. (2), is presented in Fig. 7 together with trends in tank water levels and daily precipitation. GE rates across the monsoon season appear to be driven by a combination of both tank water levels and the occurrence and magnitude of rainfall events. Tank 2, for example, has relatively lower recharge rates (positive values in Fig. 7) in the earlier part of the season, with values decreasing with the occurrence of each major rainfall event, and then increasing incrementally over time until the next rainfall. The last period of significant rainfall occurs in mid-December, and shortly after this time, recharge magnitudes for Tank 2 reach a peak, and then slowly decrease with decreasing tank water levels. A similar pattern can be seen for Tank 4, where the peak recharge value occurs during the mid-December period, followed by a steady decline in recharge magnitudes as tank water levels decrease. In contrast, Tanks 1 and 3 appear to be less impacted by rainfall events; for these tanks, recharge magnitudes begin to decrease with decreases in tank water levels much earlier in the season, after the last major rainfall $(64 \mathrm{~mm})$ on 17 November. In the last few weeks of the monsoon season, Tanks 2-4 all switch over to a groundwater inflow regime (negative GE values). Lower recharge rates as well as these switches to groundwater inflow towards the end of the season may be due to tank water levels consistently having greater declines compared to the surrounding aquifer, resulting in decreases and potential reversals of hydraulic head gradients. This period is also, however, punctuated by some distinct, very high groundwater outflow events that may correspond to observed groundwater pumping in the vicinity, highlighting a potential direct human influence to tank recharge rates.

To better characterize the dominant drivers for the magnitude and direction of GE, with the overall goal of generalizing these observations to larger scales, we plotted GE as a function of days since last rainfall for all four tanks (Fig. 8a). For Tanks 2 and 4, there is a threshold value of days since 


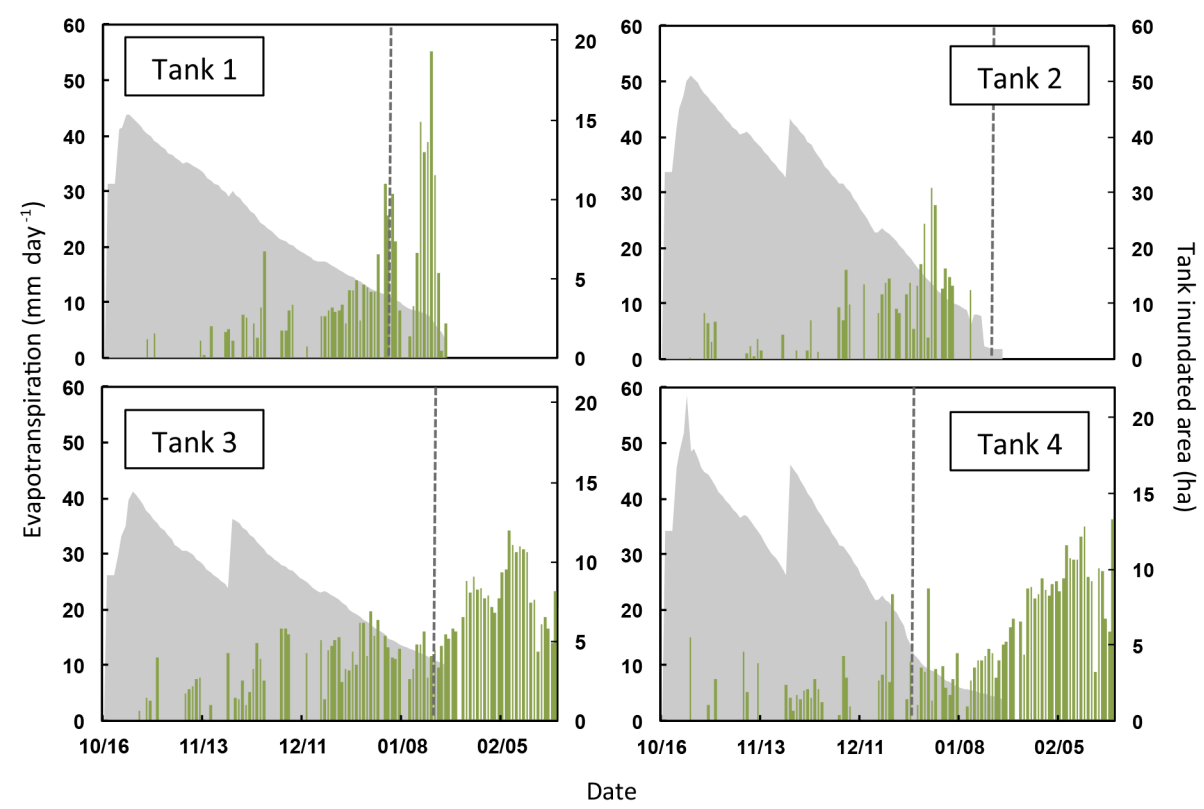

Figure 6. The temporal variation in daily ET over the monsoon season, shown as green bars. There are data gaps in the figure since estimates were made using the White method only on nonrainfall days. ET increases towards the later part of the season, coincident with decreases in tank surface area (shown as the grey shaded area). ET rates are reasonable for the region and season when the inundated area is greater than $25 \%$ of maximum area, as indicated by the dashed line.

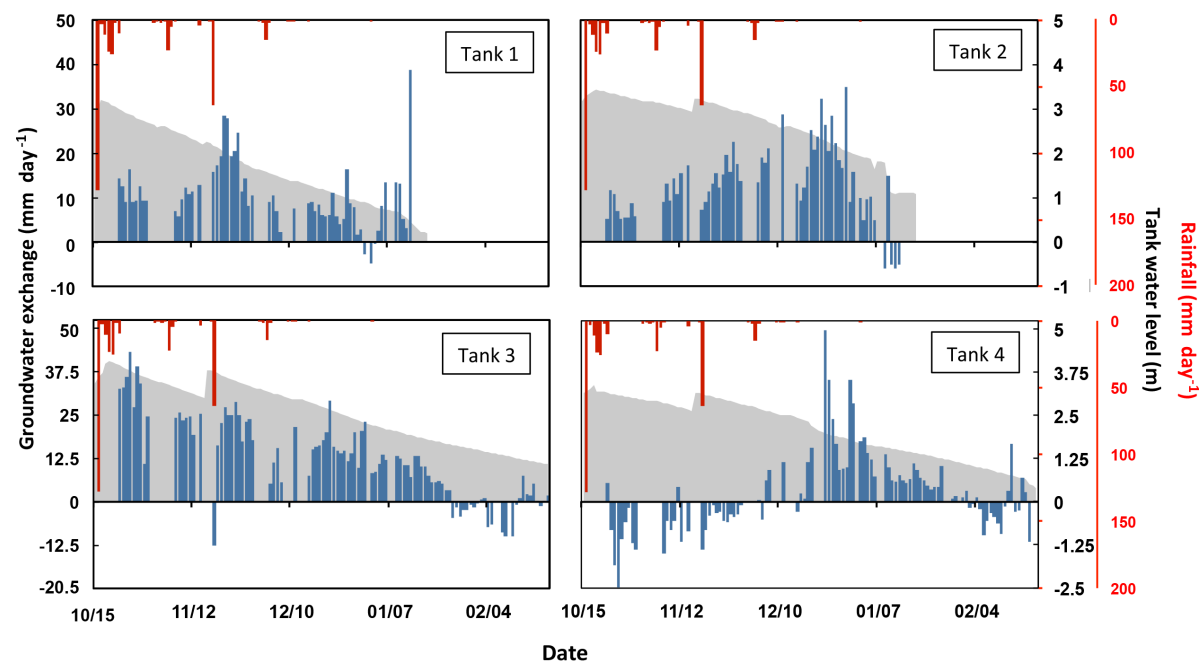

Figure 7. Daily groundwater exchange $\left(\mathrm{mm} \mathrm{d}^{-1}\right)$ over the course of the northeast monsoon season (blue bars). Positive values indicate groundwater outflow (recharge) from the tank, while negative values indicate inflow (discharge) into the tank. Groundwater exchange magnitudes generally decrease and even switch from outflow to inflow towards the latter part of the season, when tank water levels (shown in grey and plotted on the secondary $y$ axes) are low. There are in some cases some very high groundwater outflow events near the end of the season corresponding to pumping in the vicinity. Rainfall is shown as red bars.

rain (14 days for Tank 2, and 16 days for Tank 4) that separates rainfall-GE relationships. That is, there is significant scatter in the rainfall-GE relationship at values less than this threshold, but strong negative relationships emerge between the two variables at higher values of day since rain (Fig. 8a). In contrast, Tanks 1 and 3 have much lower threshold values of only 1 and 3 days, respectively. This pattern of decreasing recharge with days since last rainfall is reasonable, as water levels in the tank steadily decrease over time, leading to decreased hydraulic head and thus lower rates of recharge. In contrast, immediately following a rain event, the system becomes more dynamic, and recharge is a function of not only tank water levels but also the short-term response of the local surrounding aquifer. When plotted for all tanks, GE was 


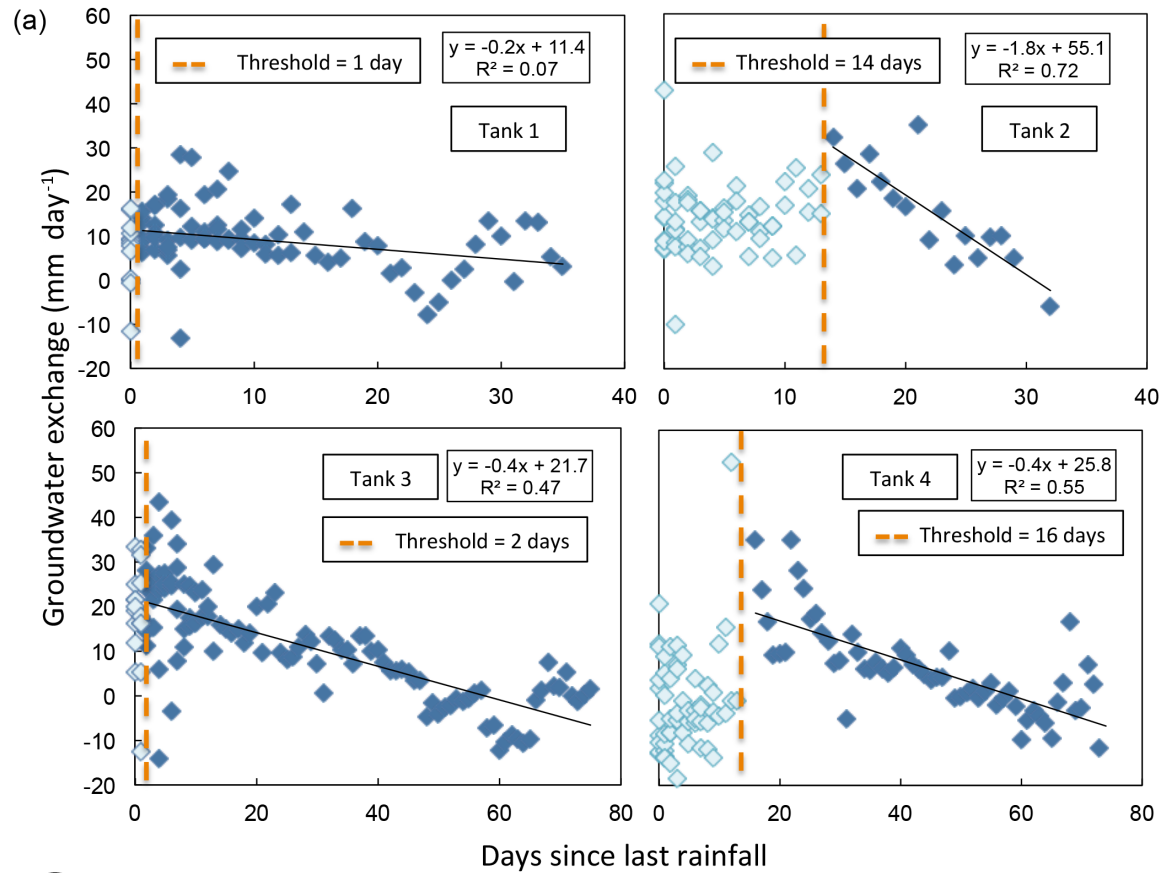

(b)

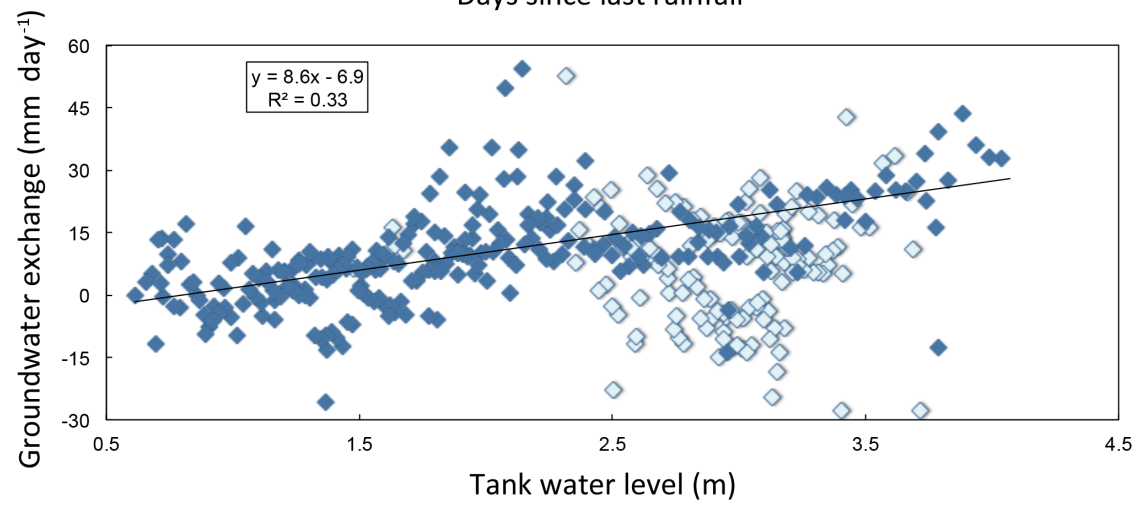

Figure 8. (a) Relationship between groundwater exchange and days since last rainfall, shown separately for the four tanks. The threshold line (dashed orange) separates the more erratic rainfall-driven groundwater exchange behavior following rain events (shown as light blue diamonds) from the more predictable behavior typical of drier periods (shown as dark blue diamonds), when GE is driven primarily by hydraulic head values determined by tank water levels. (b) Relationship between tank water levels and groundwater exchange shown for all four tanks combined. Lighter blue diamonds correspond to the rainfall values below the threshold shown above in Fig. 7a.

also found to respond linearly to tank water levels for most days throughout the monsoon season, except in the hydrologically dynamic periods after rain events, when the behavior was more erratic (Fig. 8b).

In addition to these patterns of groundwater exchange across the monsoon season, differences can also be seen along the tank cascade, from top (Tank 1) to bottom (Tank 4). First, while recharge dominates the exchange dynamics of Tanks $1-3$, Tank 4 is more discharge driven. As shown in Fig. 9a, close to $90 \%$ of all days throughout the monsoon show net recharge behavior for Tanks $1-3$, while Tank 4 is split almost equally between net recharge and net discharge days. From a volume perspective, the discharge-to-recharge ratio for the tanks shows a general trend from smaller $(0.3$ in Tank 1) to larger (1.2 in Tank 4) across the tank cascade (Fig. 9b), with Tank 4 demonstrating net discharge behavior. Tank 4 is the most downgradient tank, suggesting the possibility that aquifer levels adjacent to Tank 4 are higher (possibly due to upstream tanks' recharge) for a longer period of time than the other three tanks, leading to more frequent groundwater inflow.

Our finding of a distinct spatial pattern in groundwater exchange and sluice outflow dynamics across the tank cascade is a novel contribution of the present study. Most studies that have explored the recharge-discharge functions of tanks (Glendenning et al., 2012) have focused on individual tanks, with no consideration of the position of the tank in a cascade as an important control on its functioning. Our results 

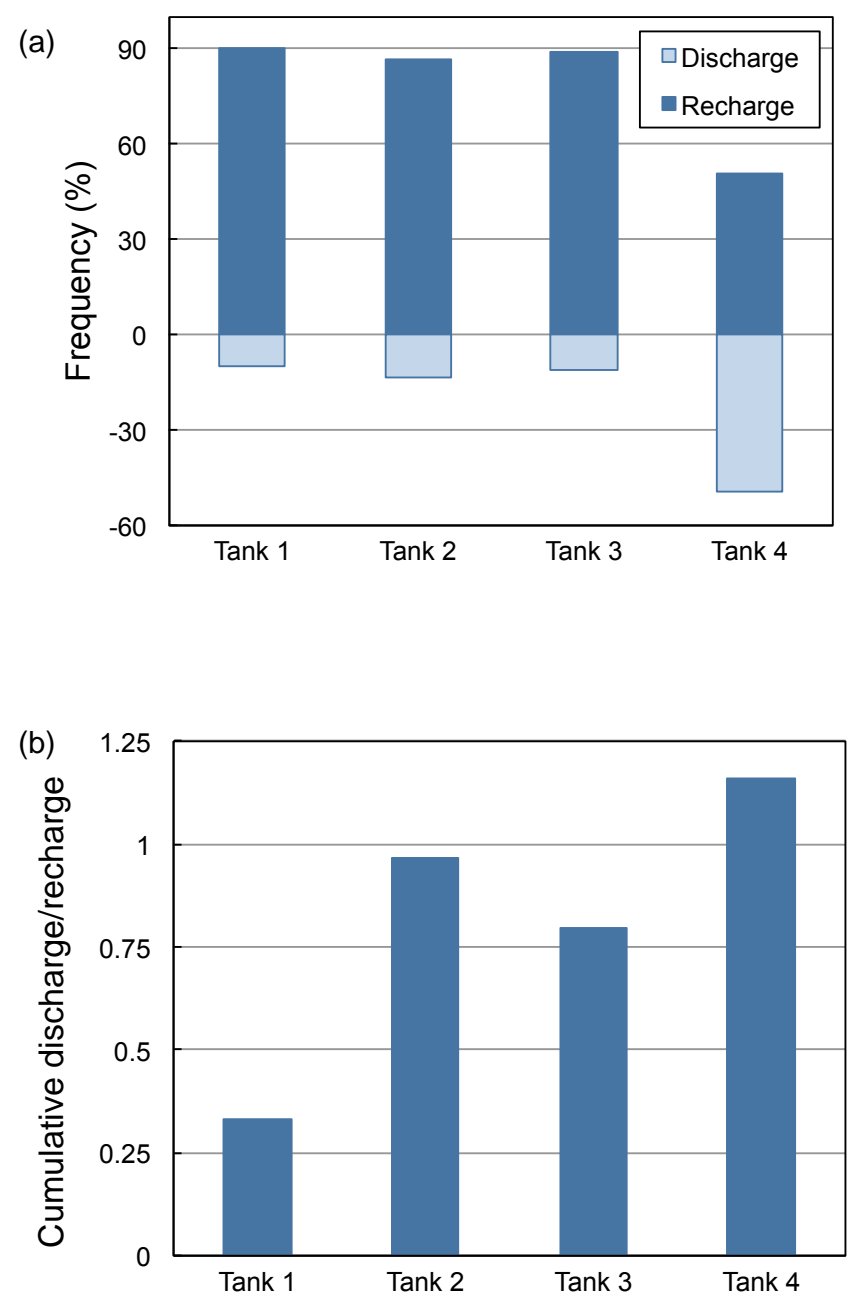

Figure 9. (a) The frequency of daily recharge (outflow) and discharge (inflow) events over the northeast monsoon season, and (b) the ratios of cumulative discharge to cumulative recharge magnitudes. The results for the four tanks indicate that all tanks function as both recharge and discharge systems, but that Tank 4 is much more dominated by discharge behavior based on both frequency and overall magnitudes.

indicate that in order to upscale tank-scale information to understand catchment and regional-scale impact of tanks, more studies should focus on exploring the spatial arrangement of tanks in the landscape.

\subsection{Exploring biophysical vs. management controls on tank water balance at the tank and catchment scales}

Three questions were posed in the introduction regarding the partitioning of water within a tank cascade, the ways in which tanks alter the catchment water balance, and the ability of tanks to meet irrigation requirements in the semi-arid landscapes of south India. Below, we use our measured data to provide answers to these questions in the context of a discus- sion of physical vs. management controls on tank functionality.

\subsubsection{Water balance at the tank scale}

The first question we asked was how tanks partition incoming surface water (direct rainfall on tank and surface runoff from tank catchment) into various outflow components, namely ET, groundwater outflow/inflow, and sluice outflow to the fields in the tank command area. The flow volumes corresponding to these components for each tank over the duration of the northeast monsoon season are plotted by week in Fig. 10a and are summarized in Table 3. Notably, recharge to groundwater is a significant component of tank outflows. Although the primary function of tanks in south India has historically been to provide surface water for irrigation, and despite the high clay content of soils in the area, groundwater recharge is the primary outflow mechanism in Tanks 1-3 (46-59\% of total outflows). For Tank 4, however, which is dominated by discharge behavior, the primary outflow mechanism is sluice outflow, which directly provides irrigation water to the tank command area. As seen in Fig. 10a, sluice outflows and recharge are the greatest early in the season, when tank levels are at their highest, and then decrease over time, ceasing entirely by mid-December for all four tanks.

Although the surface water volume lost to ET is substantial (0.48-1.64 million $\mathrm{m}^{3}$ over the 83-day study period), it is a relatively small fraction of the overall water budget. On a cumulative scale (Table 3), ET values range from $13 \%$ of total outflows for Tank 1 to $22 \%$ for Tanks 2 and 3 . These smaller percentages of ET compared to recharge contradict the established view of tanks losing a significant fraction of their water through ET (Kumar et al., 2006). In addition, although the tanks have been constructed in soils with a high clay content, all but Tank 4, which has a high discharge-recharge ratio, have high relatives rates of groundwater recharge. For Tanks 2 and 3, recharge is the largest outflow component $(57-59 \%)$ and is more than double the values for sluice outflow and evapotranspiration. For Tank 1, recharge is also the largest outflow component (47\%), although it is similar in magnitude to sluice outflows $(41 \%)$. The differences in flow partitioning between the four tanks can be attributed to differences in both natural (e.g., topographical position of the tank along the cascade) and human (e.g., sluice management) factors.

Interestingly, a trend can be seen in the relationship between total tank outflows over the monsoon season and the maximum tank capacity (Fig. 10b). As we move down the cascade of tanks, the outflow-to-capacity ratio increases, from 1.06 for Tank 1 to as high as 2.25 for Tank 4 . The outflow-to-capacity ratio is an indication of how many times a tank fills up during the season, and the increase in values along the cascade of tanks is a function of increasing return flows from upstream command areas entering the downstream tanks. For Tank 4 in particular, groundwater discharge 

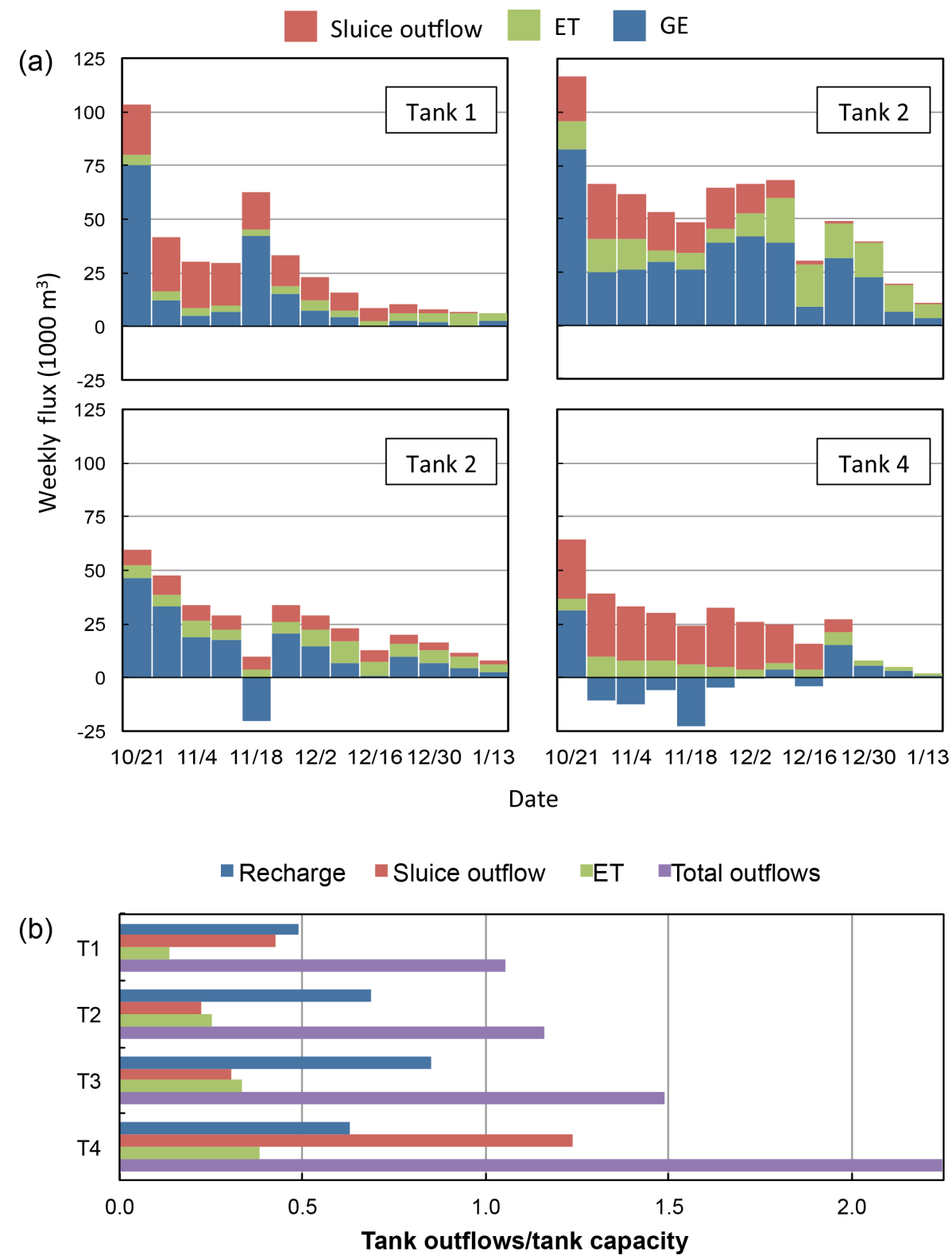

Figure 10. (a) Tank outflow dynamics (ET in green, sluice outflow in red, and GE in blue) shown as weekly integrated volumes for all four tanks. (b) Tank water outflows as a fraction of the tank capacity, with total outflows calculated as the sum of ET, $S_{0}$, and groundwater recharge. The outflow-to-capacity ratios increase down the cascade, such that total outflows for Tank 4 over the study period are more than double the total tank capacity.

provides a significant input of water into the tank (Fig. 9). Accordingly, Tank 4 has relatively greater amounts of water available for surface water irrigation throughout the season, with sluice outflow alone accounting for 1.2 times the total tank capacity. This increase in the outflow-to-capacity ratio along the cascade of tanks is an important feature of the tank cascade system, and highlights the need to study the tanks not in isolation, but in relation to their position along the cascade. Biophysical controls (e.g., weeds or sediments in tank beds of upgradient tanks) or management choices (e.g., planting crops with lower or high water requirements in upgradient tanks) can completely alter the water availability in a downstream tank. Thus, rehabilitation efforts and tank management should focus on maximizing benefits at the cascade scale instead of only at the individual tank scale.

\subsubsection{Water balance at the catchment scale}

The second question we asked was how tanks alter the partitioning of rainfall into runoff at the catchment outlet $(Q)$ 
Table 3. Partitioning of tank outflows across the northeast monsoon season.

\begin{tabular}{|c|c|c|c|c|}
\hline & Tank 1 & Tank 2 & Tank 3 & Tank 4 \\
\hline Total outflows $\left(\mathrm{m}^{3}\right)$ & 376794 & 762483 & 352934 & $377257^{*}$ \\
\hline $\begin{array}{l}\text { Evapotranspiration } \\
\text { total }\left(\mathrm{m}^{3}\right)\end{array}$ & 48291 & 164423 & 78745 & 64358 \\
\hline $\begin{array}{l}\text { Percent of total outflows } \\
\text { Sluice outflow }\end{array}$ & $13 \%$ & $22 \%$ & $22 \%$ & $17 \%$ \\
\hline total $\left(\mathrm{m}^{3}\right)$ & 153038 & 146612 & 72279 & 207636 \\
\hline $\begin{array}{l}\text { Percent of total outflows } \\
\text { Recharge }\end{array}$ & $41 \%$ & $19 \%$ & $20 \%$ & $55 \%$ \\
\hline Total $\left(\mathrm{m}^{3}\right)$ & 175465 & 451448 & 201910 & 105263 \\
\hline Percent of total outflows & $47 \%$ & $59 \%$ & $57 \%$ & $28 \%$ \\
\hline
\end{tabular}

and recharge within the catchment. Water balance calculations were done at the tank and catchment scales for the four nested catchment scenarios described in Sect. 3.4. Further, we simulated scenarios both with and without tanks to understand the contribution of tanks towards altering catchment scale water partitioning.

Our results show a dramatic difference between the withtank and no-tank scenarios, and a distinct spatial pattern of response in the four nested catchments. We found a significant decrease in $Q$ at the four nested scales, from $22 \%$ of rainfall in the no-tank scenario to 5-9\% of rainfall with tanks (Table 4). At the largest catchment scale (C4), the runoff decreased from approximately 2.29 million $\mathrm{m}^{3}$ in the NT scenario to only 0.69 million $\mathrm{m}^{3}$ in the presence of tanks (Table 4). This approximately $70 \%$ decrease is consistent with other work showing large decreases in runoff due to the presence of tanks (Kumar et al., 2008). Conversely, catchment-scale net recharge was observed to increase from $17 \%$ of rainfall without tanks to $24-27 \%$ with tanks (Table 4), which corresponds to an overall increase in net groundwater recharge of $40 \%$, highlighting the potential beneficial role tanks may play in augmenting groundwater resources.

Despite this strong link between the presence of tanks and groundwater recharge, tank maintenance has declined across south India as farmers have become increasingly reliant on groundwater irrigation sources (Balasubramanian and Selvaraj, 2003). With tank-irrigated area across Tamil Nadu having decreased from 940000 ha in 1960 to approximately 503000 ha in 2010, some suggest that current tanks are operating at only $30 \%$ of their potential capacity (Amarasinghe et al., 2009; Government of Tamil Nadu, 2011; Palanisami and Meinzen-Dick, 2001). This degradation of tank functionality is eliminating or significantly degrading the primary mechanism for aquifer recharge in an area where, without rainwater harvesting, the majority of monsoon rainfall will leave a catchment as runoff within hours of falling. Our water balance calculations show that tanks, with adequate maintenance, provide a mean groundwater recharge benefit of $5600 \mathrm{~m}^{3}$ per hectare of tank waterspread area. At the scale of the Gundar basin, with its 2276 village-scale RWH tanks, each covering an area of approximately 40 ha (DHAN, 2010), these results suggest that fully functional tanks could provide a groundwater recharge benefit of 522 million $\mathrm{m}^{3}$. With a population of approximately 3 million this difference translates to a difference in water availability throughout the Gundar basin of $174 \mathrm{~m}^{3}$ per capita. It is currently estimated that all of India is experiencing some degree of water stress, with per capita availability ranging from $1000-1700 \mathrm{~m}^{3} \mathrm{yr}^{-1}$ (Amarasinghe et al., 2005). Accordingly, maintaining tanks at full functionality has the potential to increase per capita water availability in the Gundar by approximately $10-15 \%$.

It should be noted that the recharge benefit suggested by the results in our tank cascade is significantly larger than that reported for a watershed in Gujarat, a state in western India, where it was shown that the construction of new rainwater harvesting structures would lead to a $60 \%$ decrease in catchment runoff, but only a $5 \%$ increase in recharge (Sharma and Thakur, 2007). In the Gujarat catchment, however, annual rainfall is approximately half that in our south India catchment, and ET rates are estimated at more than $50 \mathrm{~mm} \mathrm{~d}^{-1}$, suggesting that variations in climate can strongly impact the contribution of rainwater harvesting structures to groundwater recharge.

\subsubsection{Management controls on irrigation efficiency}

While the first two questions focused on the physical controls on tank water dynamics, our third question focused on understanding how tank water management affects water balances and, in doing so, contributes to meeting the irrigation require- 
Table 4. Water balance summary at the tank catchment scale.

\begin{tabular}{lllll}
\hline & Catchment 1 & Catchment 2 & Catchment 3 & Catchment 4 \\
\hline Area $\left(\mathrm{km}^{2}\right)$ & 5.0 & 16.2 & 22.5 & 28.4 \\
$\begin{array}{l}\text { Precipitation } P\left(\text { million }^{3}\right) \\
\text { Runoff } Q\left(\text { million } \mathrm{m}^{3}\right)\end{array}$ & 1.8 & 5.8 & 8.1 & 10.2 \\
$\begin{array}{l}\text { with tanks } \\
\text { without tanks }\end{array}$ & 0.15 & 0.30 & 0.37 & 0.69 \\
$\begin{array}{l}\left.\text { Recharge } R \text { (million } \mathrm{m}^{3}\right) \\
\text { with tanks }\end{array}$ & 0.40 & 1.31 & 1.81 & 2.29 \\
without tanks & 0.48 & 1.44 & 1.97 & 2.42 \\
$Q / P$ & 0.31 & 0.99 & 1.37 & 1.73 \\
with tanks & & & & \\
without tanks & 0.09 & 0.05 & 0.05 & 0.07 \\
$R / P$ & 0.22 & 0.22 & 0.22 & 0.22 \\
with tanks & & & & \\
without tanks & 0.27 & 0.25 & 0.24 & 0.24 \\
\hline
\end{tabular}

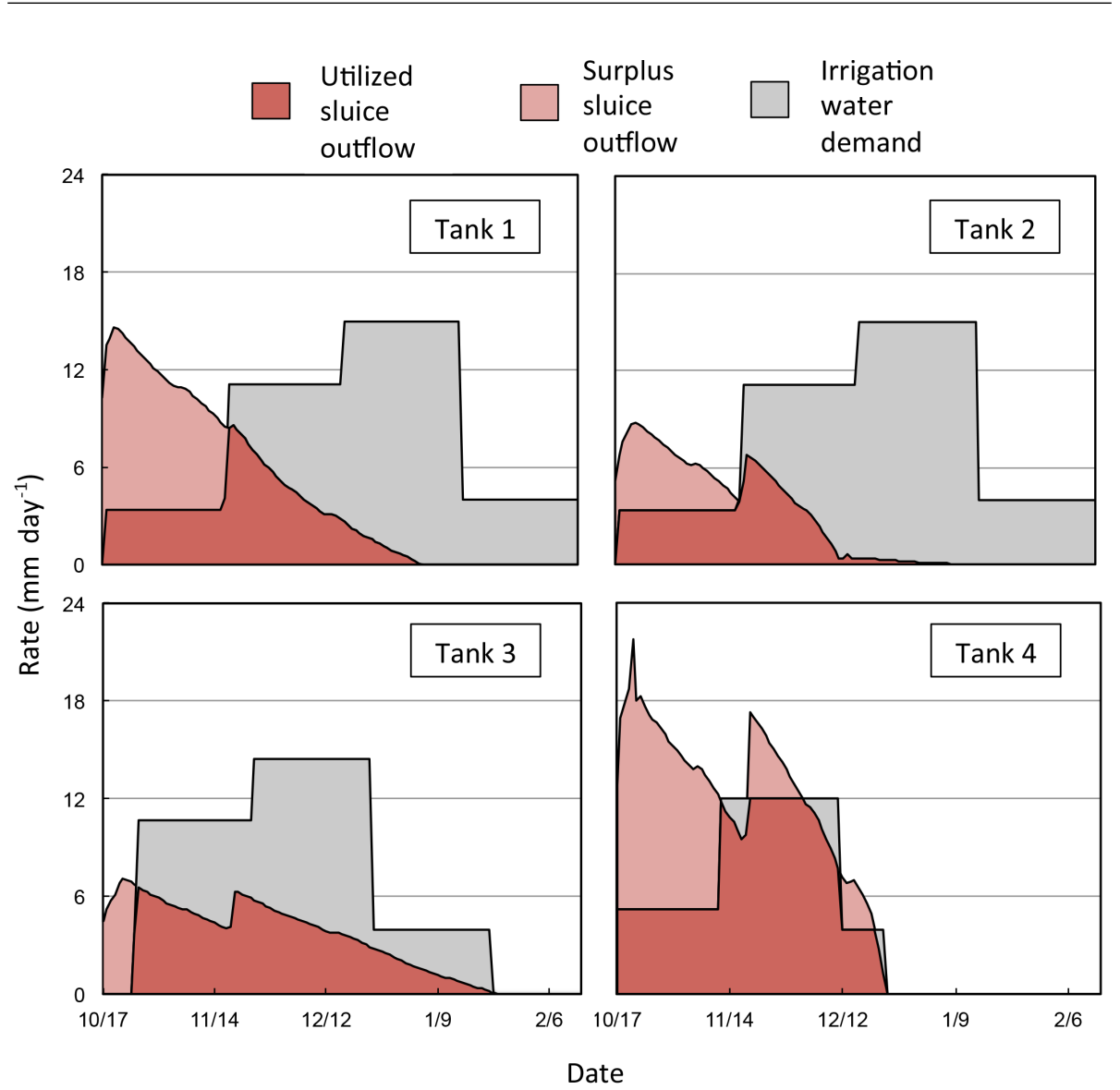

Figure 11. Water supply-and-demand portraits in our tank cascade. The grey area represents the irrigation water demand (IWD), calculated as the difference between crop water requirements and rainfall (Brouwer et al., 1989). Planting dates were 17 October, 17 October, 25 September, and 13 September, for Tanks 1,2,3, and 4, respectively. The darker red area corresponds to the portion of sluice outflow that is utilized to meet the irrigation water demand, while the light red area corresponds to the portion of sluice outflow that is not directly utilized by crops in the tank's command area.

ments of the tank command areas. To answer this question we have plotted supply-and-demand curves over the grow- ing season (Fig. 11). The supply curves are the sluice outflow volumes from the four tanks. The demand curve in this 
Table 5. Sluice outflows and irrigation water demand (IWD).

\begin{tabular}{lllll}
\hline & Tank 1 & Tank 2 & Tank 3 & Tank 4 \\
\hline Planting date & $17 / 10$ & $17 / 10$ & $25 / 09$ & $9 / 13$ \\
\hline Sluice water & & & & \\
Total (mm) & 570 & 326 & 391 & 861 \\
Utilized (mm) & 283 & 210 & 333 & 516 \\
Surplus (mm) & 287 & 116 & 58 & 345 \\
Percent surplus & $50 \%$ & $36 \%$ & $15 \%$ & $40 \%$ \\
\hline Irrigation water demand & & & & \\
Total (mm) & 996 & 996 & 872 & 752 \\
Unmet demand (mm) & 713 & 786 & 540 & 235 \\
Percent unmet & $72 \%$ & $79 \%$ & $62 \%$ & $31 \%$ \\
\hline
\end{tabular}

case is the crop water requirement in $\mathrm{mm} \mathrm{d}^{-1}$, which is adjusted by the available rainfall to get the irrigation water demand (IWD is equivalent to the rainfall subtracted from the crop water requirement). The crop water requirement data in $\mathrm{mm} \mathrm{d}^{-1}$ were obtained from Brouwer et al. (1989) for the four growing stages of paddy. Paddy planting dates, which differed dramatically between the four tanks (17 October, 17 October, 25 September, and 13 September for Tanks 1, 2, 3, and 4), are based on field observations. The earlier planting dates in the command areas of Tanks 3 and 4 were most likely due to the availability of borewell water for those areas. As can be seen in Fig. 11, the difference in planting dates leads to different demand curves for the four tanks.

The supply-and-demand curves assess the ability of the tanks to meet paddy water demand by comparing IWDs to sluice outflows. The darker red areas in Fig. 11 denote sluice water used to meet the IWD, while the lighter red areas represent sluice water that is flowing out at a time when crops are not requiring that water. The grey areas in the figure represent the IWD unmet by sluice outflow. Notably, large quantities of surplus sluice water leave the tank soon after it fills. These surplus sluice outflows are not needed by the crops at the time they leave the tank and will either leave the catchment as evaporation or downstream runoff, or will recharge groundwater over the course of the outflow channel and become available to downstream users. Because the sluices are for the most part not actively managed or appropriately maintained in our study area, the sluices remaining perpetually open and outflows are purely a function of water levels in the tank rather than a timed need for irrigation water. As reported in Table 5, it was found that anywhere from 31-79\% of IWD within the study cascade remains unmet, while approximately $15-50 \%$ of available sluice outflows leave the tank unutilized by crops in the tank command areas. This remaining irrigation water demand in many cases must be met by farmers using groundwater pumping to supplement tank water, and in other cases remains unmet, leading to reduced yields or crop failure. In the case of groundwater pumping, it should be noted that a significant portion of the tank water does leave the tanks as groundwater outflow, and is subsequently extracted by groundwater wells for irrigation, thus helping to meet the crop water requirements by an indirect route. The magnitude of this contribution of tank outflows to the crop water budget, however, is difficult to ascertain, and thus has not been included herein.

The timing of planting also has a significant impact on the ability of the tanks to meet crop water requirements (Fig. 11), with the later planting dates in Tanks 1 and 2 leading to more than $70 \%$ of the IWD being unmet by sluice outflows (Table 5). Conversely, Tank 4, with its much earlier planting time (13 September), more effectively meets crop water requirements with sluice outflow. First, the early planting time leads to the lowest total IWD of all the tanks $(752 \mathrm{~mm})$, as more of the crop water requirements can be met by rainfall. In addition, there is a better temporal match for Tank 4 between the unregulated sluice outflows at high tank water levels (Fig. 11) and the crop water needs of the plants. Accordingly, more than $500 \mathrm{~mm}$ of the IWD is met by sluice outflows, and only $31 \%$ of the overall demand remains unmet. These results suggest that, to optimize tank operations and to maximize the water-provisioning capabilities of the tanks, earlier planting times could be adopted by farmers, with supplemental irrigation from groundwater being utilized until the tanks fill. Such a change in management, however, would be dependent on both groundwater availability and the economics of groundwater pumping. Indeed, interactions with the villagers revealed that the earlier planting dates in the downgradient tanks could be attributed to the greater availability of groundwater in that region, which enables the farmers to plant before the monsoons have arrived.

\section{Conclusion}

In recent decades, there has been growing interest in the revival and expanded use of rainwater harvesting tanks across the agricultural landscapes of India and other semi-arid regions to address issues of water scarcity and aquifer depletion. While it is well established that these tanks can increase local water availability, leading to higher crop yields and direct socioeconomic benefits (Palanisami et al., 2010), the impact of widespread use of small, distributed storage reservoirs on the catchment-scale partitioning of water resources is still an open question. Furthermore, while significant resources are being used to rehabilitate tanks, there is a lack of understanding regarding how these ancient structures function in a modern landscape, under current socioeconomic and environmental pressures. The hydrology of these tanks is so intricately tied with the social system in which they are embedded that only a system approach, accounting for interactions between natural and human systems, can allow us to fully understand and manage these systems. Accordingly, any full analysis of tank water dynamics must be carried out 
within the domain of the emerging science of sociohydrology (Sivapalan et al., 2012).

In this paper we have used high-resolution monitoring of tank water levels to help quantify daily fluxes of evapotranspiration, groundwater recharge, and sluice outflows from the tanks, and have coupled this information with village-level data on planting dates and irrigated areas, to further our understanding of natural and human controls on water partitioning at both tank and catchment scales. At the tank scale, groundwater recharge and sluice outflow were observed to be the largest components of the tank water budget, with ET accounting for only 13-22\% of the outflows, including open water evaporation and ET of plants transpiring in the tank bed. At the catchment scale, our results demonstrate that the presence of tanks within the catchment decreases runoff by approximately $70 \%$, increases recharge by $40 \%$, and directly satisfies approximately $40 \%$ of crop water requirements across the northeast monsoon season via surface water irrigation. These findings suggest that village-scale rainwater harvesting tanks can dramatically increase water availability at a local or village scale, but also may have negative impacts on downstream users due to large decreases in catchment runoff. Our results also highlight that, despite ongoing the efforts toward tank rehabilitation in our study cascade, a lack of sluice maintenance leads to a large fraction of tank water not being available for use in the tank command area. Thus, a more efficient management of sluice outflows, and better maintenance of the sluices themselves, could lead to the tanks meeting a higher fraction of crop water requirements.

An interesting and novel attribute of our study is the exploration of biophysical and social controls on tank water dynamics as a function of the location of the tank along a cascade, in a four-tank cascade system. We observe a distinct spatial pattern in groundwater-exchange dynamics with the most downgradient tank being mostly driven by groundwater inflow, while the other tanks are more outflow driven. Consequently the most downgradient tank has a much greater outflow-to-capacity ratio, and is able to provide a much larger volume of sluice outflow compared to its capacity. The ability of the most downgradient tank to provide more irrigation water is a function of the return flow from the command areas of the upstream tanks and highlights the need to study tanks, not in isolation, but as a part of a cascade. There is also a distinct pattern in the crop planting dates in the four tanks, with the more downgradient tanks having earlier planting dates, due to greater availability of groundwater, thus leading to a more efficient use of tank water. This dynamic highlights the feedbacks between the natural and human systems, where a greater availability of water at the catchment outlet leads to farmers deciding on earlier planting dates, which in turn leads to a more efficient use of the available water.

In conclusion, our results demonstrate the significant role that tanks can play in addressing challenges of limited water availability, by both increasing groundwater recharge as well as the water available for irrigation. However, they also draw attention to the potentially negative environmental impacts of tanks with respect to reducing downstream flows. These findings highlight the need to understand the spatiotemporal patterns in tank water dynamics at the basin scale, especially within the framework of a coupled natural and human systems approach that allows a more complete understanding of how tanks alter the sociohydrological dynamics of waterstressed landscapes. Thus, ongoing rehabilitation efforts of tanks must be complemented by more studies that quantify the functioning of these rehabilitated tanks and their impacts in altering basin-scale water dynamics, with the overall goal of appropriately managing tradeoffs between socioeconomic benefits and environmental costs.

Author contributions. The field study was carried out by Michael Steiff under the guidance of Daniel L. McLaughlin. Data analysis was carried out by Kimberly J. Van Meter and Michael Steiff. Drafting of the manuscript was led by Kimberly J. Van Meter and Nandita B. Basu, with contributions by Daniel L. McLaughlin. Nandita B. Basu conceived of the project and was instrumental to the basic experimental design.

Acknowledgements. This research is financially supported by the US National Science Foundation (1211968), Dynamics of Coupled Natural-Human Systems and by the University of Waterloo start-up funds. We thank the DHAN Foundation for generously sharing their experiences, data, and hospitality during the two field visits that allowed us to carry out this project. We would also like to thank K. Palanisami for his help with establishing connections for the research team within India and with his guidance regarding field site selection.

Edited by: A. Mejia

\section{References}

Agarwal, A. and Narain, S.: Dying Wisdom: Rise, Fall and Potential of India's Traditional Water Harvesting Systems, (Centre for Science and Environ, 1997.

Amarasinghe, U., Sharma, B. R., Aloysius, N., Scott, C., Smakhtin, V., and Fraiture, C. de: Spatial Variation in Water Supply and Demand Across River Basins of India, IWMI, 2005.

Amarasinghe, U. A., Singh, O. P., Sakthivadivel, R., and Palanisami, K.: State of irrigation in Tamil Nadu: trends and turning points, Strateg. Anal. Natl. River Link. Proj. NRLP India Ser. 5, 275-304, 2009.

Anbumozhi, V., Matsumoto, K., and Yamaji, E.: Towards improved performance of irrigation tanks in semi-arid regions of India: modernization opportunities and challenges, Irrig. Drain. Syst., 15, 293-309, 2001.

Anuraga, T. S., Ruiz, L., Kumar, M. S. M., Sekhar, M., and Leijnse, A.: Estimating groundwater recharge using land use and soil data: A case study in South India, Agr. Water Manage., 84, 65-76, 2006. 
Balasubramanian, R. and Selvaraj, K. N.: Poverty, private property, and common pool resource management: the case of irrigation tanks in South India, South Asian Network for Development and Environmental Economics, Kathmandu, 1-61, 2003.

Batchelor, C. H., Rama Mohan Rao, M. S., Manohar Rao, S., and others: Watershed development: A solution to water shortages in semi-arid India or part of the problem, Land Use Water Resour. Res., 3, 1-10, 2003.

Bouma, J. A., Biggs, T. W., and Bouwer, L. M.: The downstream externalities of harvesting rainwater in semi-arid watersheds: An Indian case study, Agric. Water Manag., 98, 1162-1170, doi:10.1016/j.agwat.2011.02.010, 2011.

Brouwer, C., Prins, K., and Heibloem, M.: Irrigation Water Management: Irrigation Scheduling, FAO, available at: http://www. fao.org/docrep/t7202e/t7202e00.HTM (last access: 17 October 2015), 1989.

Calder, I., Gosain, A., Rao, M. S. R. M., Batchelor, C., Snehalatha, M., and Bishop, E.: Watershed development in India. 1. Biophysical and societal impacts, Environ. Dev. Sustain., 10, 537-557, doi:10.1007/s10668-006-9079-7, 2008a.

Calder, I., Gosain, A., Rao, M. S. R. M., Batchelor, C., Garratt, J., and Bishop, E.: Watershed development in India. 2. New approaches for managing externalities and meeting sustainability requirements, Environ. Dev. Sustain., 10, 427-440, doi:10.1007/s10668-006-9073-0, 2008b.

Carlson Mazur, M. L., Wiley, M. J., and Wilcox, D. A.: Estimating evapotranspiration and groundwater flow from water-table fluctuations for a general wetland scenario, Ecohydrology, 7, 378390, doi:10.1002/eco.1356, 2014.

CGWB (Central Ground Water Board): Aquifer Systems of Tamil Nadu and Puducherry, Central Ground Water Board, Chennai, 1-78, 2012.

Cullet, P. and Gupta, J.: India: evolution of water law and policy, in: The Evolution of the Law and Politics of Water, 157-173, Springer, available at: http://link.springer.com/chapter/10.1007/ 978-1-4020-9867-3_10 (last access: 7 June 2015), 2009.

DHAN: Development of Humane Action (DHAN), available at: http://www.dhan.org/themes/vtadp.php (last access: 21 July 2015), 2010.

Drexler, J. Z., Snyder, R. L., Spano, D., and Paw, U. K. T.: A review of models and micrometeorological methods used to estimate wetland evapotranspiration, Hydrol. Process., 18, 2072101, 2004.

Farmer, B. H.: Green revolution? Technology and change in rice - growing areas of Tamil Nadu and Sri Lanka, Westview Press, Boulder, CO, 1-429, 1977.

Garg, K. K., Wani, S. P., Barron, J., Karlberg, L., and Rockstrom, J.: Up-scaling potential impacts on water flows from agricultural water interventions: opportunities and trade-offs in the Osman Sagar catchment, Musi sub-basin, India, Hydrol. Process., 27, 3905-3921, doi:10.1002/hyp.9516, 2013.

Glendenning, C. J., van Ogtrop, F. F., Mishra, A. K., and Vervoort, R. W.: Balancing watershed and local scale impacts of rain water harvesting in India - A review, Agric. Water Manag., 107, 1-13, doi:10.1016/j.agwat.2012.01.011, 2012.

Gohar, A. A., Ward, F. A., and Amer, S. A.: Economic performance of water storage capacity expansion for food security, J. Hydrol., 484, 16-25, doi:10.1016/j.jhydrol.2013.01.005, 2013.
Government of India: Census of India: Census Data Online, [online] Available at: http://censusindia.gov.in/2011-common/ censusdataonline.html (last access: 6 August 2015), 2011.

Government of Tamil Nadu: Season and Crop Report Tamil Nadu 2009-10, 352, 2011.

Grey, D. and Sadoff, C. W.: Sink or Swim? Water security for growth and development, Water Policy, 9, 545-571, doi:10.2166/wp.2007.021, 2007.

Gunnell, Y. and Krishnamurthy, A.: Past and present status of runoff harvesting systems in dryland peninsular India: A critical review, AMBIO J. Hum. Environ., 32, 320-324, 2003.

Gupta, S. K. and Deshpande, R. D.: Water for India in 2050: firstorder assessment of available options, Curr. Sci., 86, 1216-1224, 2004.

Haile, M.: Weather patterns, food security and humanitarian response in sub-Saharan Africa, Philos. Trans. R. Soc. B Biol. Sci., 360, 2169-2182, doi:10.1098/rstb.2005.1746, 2005.

Healy, R. W. and Cook, P. G.: Using groundwater levels to estimate recharge, Hydrogeol. J., 10, 91-109, 2002.

Hill, A. J. and Durchholz, B.: Specific Yield Functions for Estimating Evapotranspiration from Diurnal Surface Water Cycles, J. Am. Water Resour. Assoc., 51, 123-132, doi:10.1111/jawr.12237, 2015.

Holmes, R. M. and Robertson, G. W.: Conversion of latent evaporation to potential evapotranspiration, Can. J. Plant Sci., 38, 164172, 1958.

Hundertmark, W. and Facon, T.: Options for effective rice water management, in Proceedings of the 20th session of the International Rice Commission, Ganfkok, Thailand, 23-26 July 2002, Sustainable rice production for food security, 145-170, Food and Agriculture Organization of the United Nations, Bangkok, Thailand, available at: http://www.fao.org/docrep/006/y4751e/ y4751e0j.htm (last access: 7 October 2015), 2003.

Hvorslev, M. J.: Time lag and soil permeability in ground-water observations, US Corps of Engineers, Vicksburg, Mississippi, available at: http://trid.trb.org/view.aspx?id=124794 (last access: 22 March 2016), 1951.

Keller, A. A., Sakthivadivel, R., and Seckler, D. W.: Water Scarcity and the Role of Storage in Development, IWMI, 2000.

Kumar, M. D., Ghosh, S., Patel, A., Singh, O. P., and Ravindranath, R.: Rainwater harvesting in India: some critical issues for basin planning and research, Land Use Water Resour. Res., 6, 1-17, 2006.

Kumar, M. D., Patel, A., Ravindranath, R., and Singh, O. P.: Chasing a Mirage: Water Harvesting and Artificial Recharge in Naturally Water-Scarce Regions, Econ. Polit. Wkly., 43, 61-71, doi:10.2307/40278725, 2008.

Latha, M., Rajendran, M., and Murugappan, A.: Comparison of GIS based SCS-CN and Strange table Method of Rainfall-Runoff Models for Veeranam Tank, Tamil Nadu, India., Int. J. Sci. Eng. Res., 3, 1-5, 2012.

Loheide, S. P.: A method for estimating subdaily evapotranspiration of shallow groundwater using diurnal water table fluctuations, Ecohydrology, 1, 59-66, doi:10.1002/eco.7, 2008.

Loheide, S. P., Butler, J. J., and Gorelick, S.: Estimation of groundwater consumption by phreatophytes using diurnal water table fluctuations: A saturated-unsaturated flow assessment, Water Resour. Res., 41, doi:10.1029/2005WR003942, 2005. 
McLaughlin, D. L. and Cohen, M. J.: Realizing ecosystem services: wetland hydrologic function along a gradient of ecosystem condition, Ecol. Appl., 23, 1619-1631, 2013.

McLaughlin, D. L. and Cohen, M. J.: Ecosystem specific yield for estimating evapotranspiration and groundwater exchange from diel surface water variation, Hydrol. Process., 28, 1495-1506, doi:10.1002/hyp.9672, 2014.

McLaughlin, D. L., Kaplan, D. A., and Cohen, M. J.: A significant nexus: Geographically isolated wetlands influence landscape hydrology, Water Resour. Res., 50, 7153-7156, doi:10.1002/2013WR015002, 2014.

Mehta, L.: The manufacture of popular perceptions of scarcity: dams and water-related narratives in Gujarat, India, World Dev., 29, 2025-2041, 2001.

Mialhe, F., Gunnell, Y., and Mering, C.: Synoptic assessment of water resource variability in reservoirs by remote sensing: General approach and application to the runoff harvesting systems of south India, Water Resour. Res., 44, W05411, doi:10.1029/2007WR006065, 2008.

Mitsch, W. J. and Gosselink, J. G.: Wetlands, Hoboken, John Wiley \& Sons, Inc., 2007.

Neumann, I., MacDonald, D., and Gale, I.: Numerical approaches for approximating technical effectiveness of artificial recharge structures, Commissioned Report, British Geological Survey, Keyworth, Nottingham, available at: http://nora.nerc.ac.uk/3230/ 1/RR05001.pdf (last access: 2 February 2014), 2004.

Ngigi, S. N.: What is the limit of up-scaling rainwater harvesting in a river basin?, Phys. Chem. Earth, 28, 943-956, doi:10.1016/j.pce.2003.08.015, 2003.

Oki, T.: Global Hydrological Cycles and World Water Resources, Science, 313, 1068-1072, doi:10.1126/science.1128845, 2006.

Palaniappan, S. P., Balasubramanian, R., Ramesh, T., Chandrasekaran, A., Mani, K. G., Velayutham, M., and Lal, R.: Sustainable Management of Dryland Alfisols (Red Soils) in South India, J. Crop Improv., 23, 275-299, doi:10.1080/15427520902809888, 2009.

Palanisami, K. and Meinzen-Dick, R.: Tank performance and multiple uses in Tamil Nadu, South India, Irrig. Drain. Syst., 15, 173195, 2001.

Palanisami, K., Meinzen-Dick, R., and Giordano, M.: Climate change and water supplies: options for sustaining tank irrigation potential in India, Rev. Agric. Econ. Polit. Wkly., 45, 183-190, 2010.

Pandey, P. K., Soupir, M. L., Singh, V. P., Panda, S. N., and Pandey, V.: Modeling Rainwater Storage in Distributed Reservoir Systems in Humid Subtropical and Tropical Savannah Regions, Water Resour. Manag., 25, 3091-3111, doi:10.1007/s11269-0119847-5, 2011.

Pandey, P. K., van der Zaag, P., Soupir, M. L., and Singh, V. P.: A new model for simulating supplemental irrigation and the hydro-economic potential of a rainwater harvesting system in humid subtropical climates, Water Resour. Manag., 27, 3145-3164, 2013.

Paraskevas, C., Georgiou, P., Ilias, A., Panoras, A. and Babajimopoulos, C.: Evapotranspiration and simulation of soil water movement in small area vegetation, Int. Agrophys., 27, 445-453, 2013.
Parish, E. S., Kodra, E., Steinhaeuser, K., and Ganguly, A. R.: Estimating future global per capita water availability based on changes in climate and population, Comput. Geosci., 42, 79-86, doi:10.1016/j.cageo.2012.01.019, 2012.

Pathak, P., El-Swaify, S. A., Singh, S., Raghavan, N., and Beckerman, S. R.: Alfisols in the Semi-Arid Tropics. in Proceedings of the Consultants' Workshop on the State of the Art and Management Alternatives for Optimizing the Productivity of SAT Alfisols and Related Soils 1-44, International Crops Research Institute for the Semi-Arid Tropics., 1987.

Rockstrom, J., Barron, J., and Fox, P.: Rainwater management for increased productivity among small-holder farmers in drought prone environments, Phys. Chem. Earth, 27, 949-959, 2002.

Shah, T.: Water and Welfare: Critical Issues in India's Water Future, Econ. Polit. Wkly., 39, 1211-1213, doi:10.2307/4414796, 2004.

Shanmugham, C. R. and Kanagavalli, J.: Technology of Tanks: The Traditional Water Bodies of Rural India, Reflection Publications Trust, Madurai, India, 2013.

Sharda, V. N., Kurothe, R. S., Sena, D. R., Pande, V. C., and Tiwari, S. P.: Estimation of groundwater recharge from water storage structures in a semi-arid climate of India, J. Hydrol., 329, 224-243, doi:10.1016/j.jhydrol.2006.02.015, 2006.

Sharma, A. K. and Thakur, P. K.: Quantitative assessment of sustainability of proposed watershed development plans for kharod watershed, western India, J. Indian Soc. Remote Sens., 35, 231 241, 2007.

Sivapalan, M., Savenije, H. H. G., and Blöschl, G.: Sociohydrology: A new science of people and water, Hydrol. Process., 26, 1270-1276, doi:10.1002/hyp.8426, 2012.

van der Zaag, P. and Gupta, J.: Scale issues in the governance of water storage projects, Water Resour. Res., 44, W10417, doi:10.1029/2007WR006364, 2008.

Van Meter, K. J. V., Basu, N. B., Tate, E., and Wyckoff, J.: Monsoon Harvests: The Living Legacies of Rainwater Harvesting Systems in South India, Environ. Sci. Technol., 48, 4217-4225, doi:10.1021/es4040182, 2014.

von Oppen, M. and Subba Rao, K. V.: Tank Irrigation in Semi-Arid Tropical India, Research Bulletin, International Crops Research Institute for the Semi-Arid Tropics, Patancheru, Andrha Pradesh, 1987.

Vose, R. S., Schmoyer, R. L., Steurer, P. M., Peterson, T. C., Heim, R., Karl, T. R. and Eischeid, J.: The Global Historical Climatology Network: Long-term monthly temperature, precipitation, sea level pressure, and station pressure data, Oak Ridge National Laboratory Oak Ridge, Tennessee. [online] available at: ttp://www.nativefishlab.net/library/textpdf/12377.pdf (Accessed 7 October 2015), 1992.

Wada, Y., Gleeson, T., and Esnault, L.: Wedge approach to water stress, Nat. Geosci., 7, 615-617, 2014.

Weiz, B.: Water Reservoirs in South India: An Anthropological Approach, Diss., 30, 1-299, 2005.

Wiltshire, A., Gornall, J., Booth, B., Dennis, E., Falloon, P., Kay, G., McNeall, D., McSweeney, C., and Betts, R.: The importance of population, climate change and $\mathrm{CO}_{2}$ plant physiological forcing in determining future global water stress, Global Environ. Change, 23, 1083-1097, 2013. 